$$
\begin{aligned}
& \text { السلوك التنافسي لدى اللاعبات في الأندية الرياضية }
\end{aligned}
$$

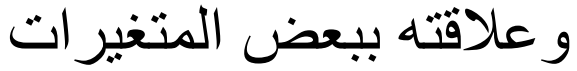

$$
\text { م.م .أحمد قاسم م.م.م.زعدي عمر }
$$

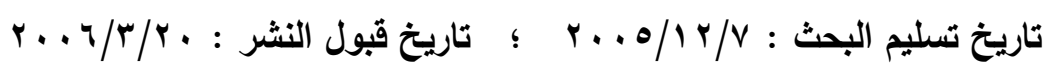

هدفت هذه الدراسة الى التعرف على مستوى السلوك التنافسي لدى اللاعبات في الأندية

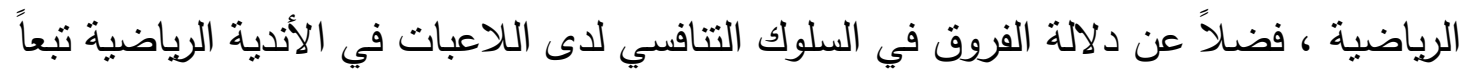

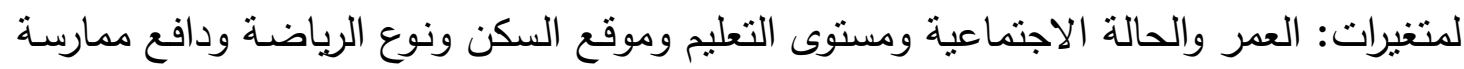
الرياضة والحصول على الجوائز والنادي .

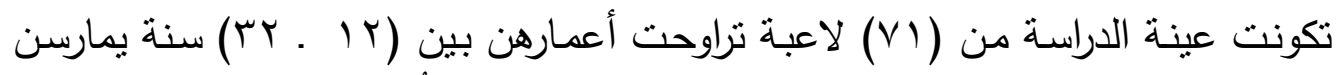

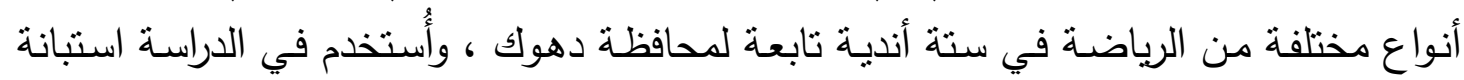
أعدها الباحثون تضمنت (·r) فقرة ، ولكل فقرة ثلاث بدائل للإجابة هي (دائماً ، أحياناً، أبداً )

وبعد تحليل البيانات الواردة في البحث باستخدام الاختبار التائي لعينة واحدة ولعينتين

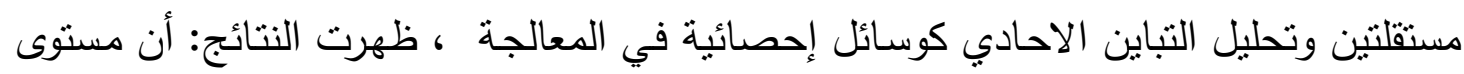

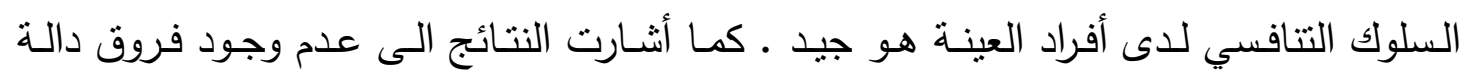

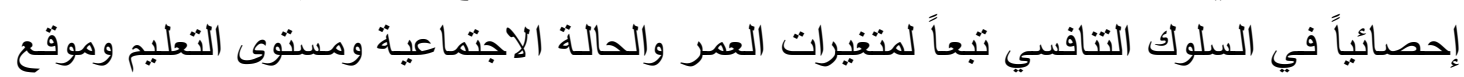

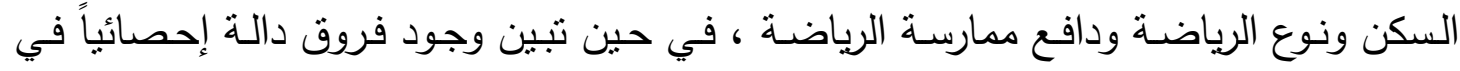

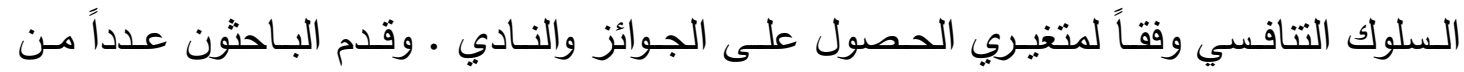
التوصيات في ضوء النتائج الني انتهت اليها الدراسة .

\title{
Competitive Behavior of Female Players in Sporting Clubs and It's Relation with Some Variables
}

\section{Ahmed K. Al-Ayoty Zead Mahfoth Sady Omer University of Dohok - College of Sport Education}

\section{Abstract:}

This paper aims at measuring the level of competitive behavior for female players in sporting clubs. It also tries to find out significant 
differences concerning the level of competitive behavior, with regard to such variables as age, social status, level of education, residing, the type of sport, motivation to sport practice, to get rewards and the club.

The sample consists of (71) female players whose ages ranged from 12-32 years who are practicing different kinds of sports in six clubs in Duhook governorate. The researchers used a questionnaire with twenty items each of which has three alternatives scales (always, sometimes, never) .

The researchers analyzed the data by using t-test for one and two samples and analysis of variance. The findings show that the level of competitive behavior for female players is good. There are no significant differences in competitive behavior with regard to age, social status, level of education, residing, type of sport and motivation to sport practice. However, there are significant differences in competitive behavior concerning such variables as getting a reward and club. The researchers put forwards some recommendations.

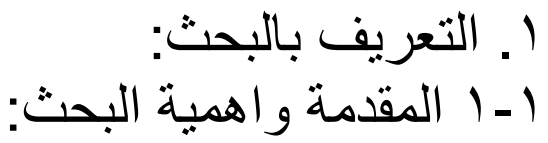

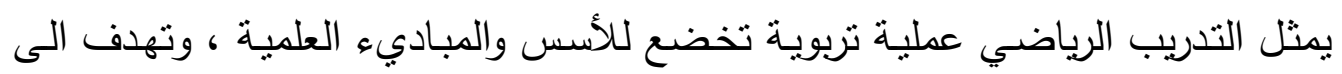

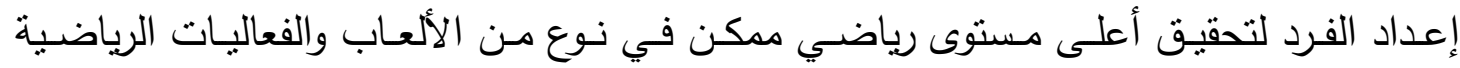
المتتلفة ـ فمن أجل الوصول الى البطولات الدولية والأولمبية أو حتى الوطنية لابد من الاستعانة

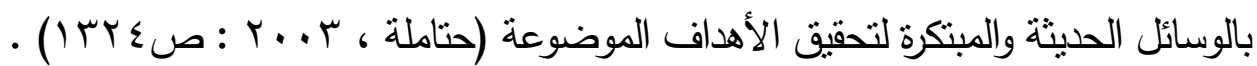

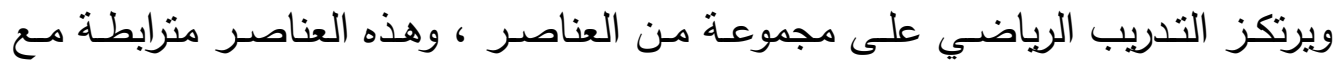

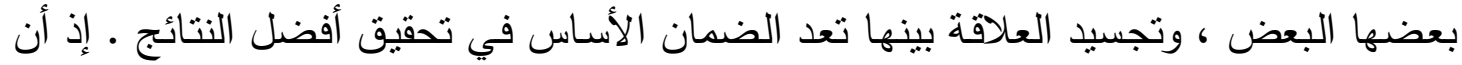
النجاح في أية لعبة يتطلب توفر مجموعة من المنطلبات الضرورية المتمثلة في العناصر البدنية

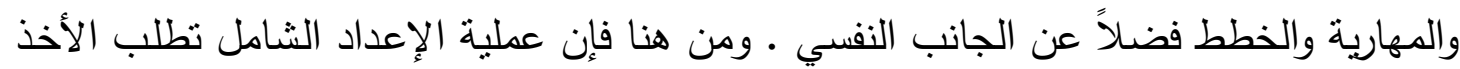
بنظر الاعنبار هذه العناصر ، والرياضي الجيد هو الذي يمتلك تكاملاً بين الخطط الجيدة

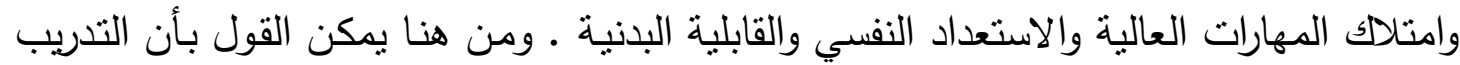
الرياضي يرتكز على العناصر الأساسية الآتية : 


$$
\begin{aligned}
& \text { أ. الإعداد البدني (تطوير الصفات البدنية والقدرات الحركية). } \\
& \text { ب. الإعداد الفني (تطوير المهارات). } \\
& \text { ج. الإعداد الخططي (تطوير التكنيك). }
\end{aligned}
$$

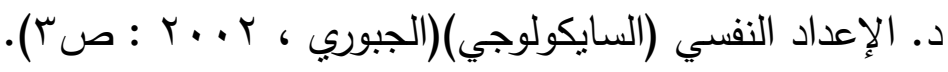

وأثناء الإعداد النفسي للرياضيين ينبغي أن يأخذ المدربين بنظر الاعنبار صنار مسألة السلوك

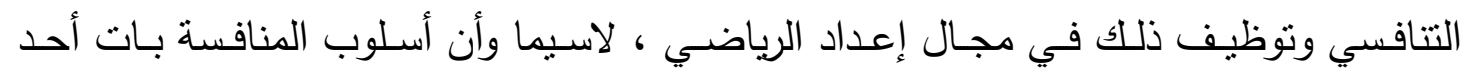

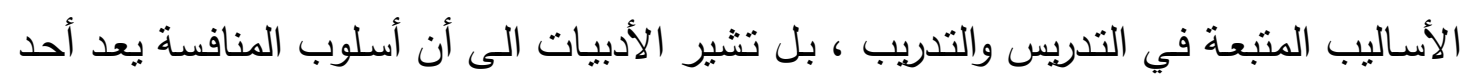

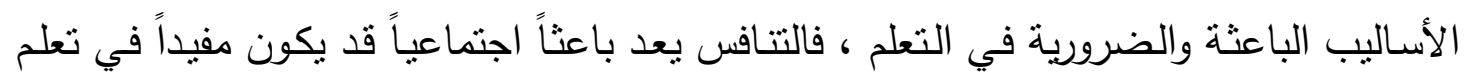

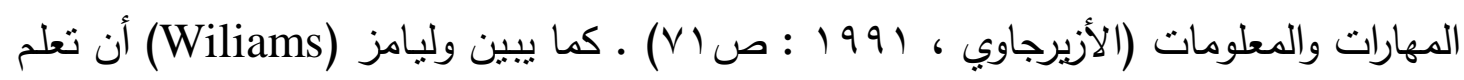
المهارات الحركية يتضمن الانتباه الانتقائي والذي يتم من خلاله توجيه انتباه المتعلم نحو الأبعاد

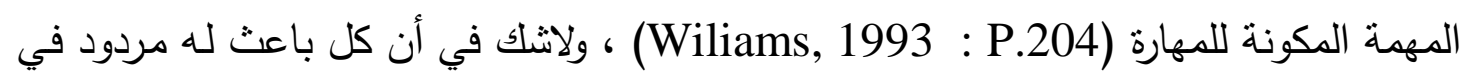
- التعلم

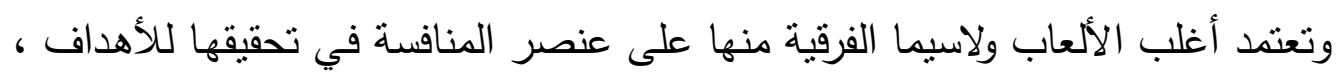

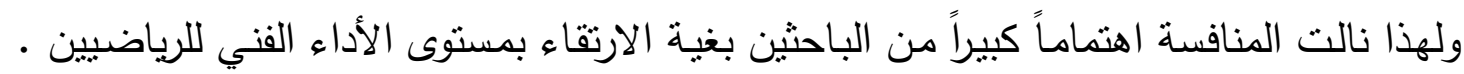

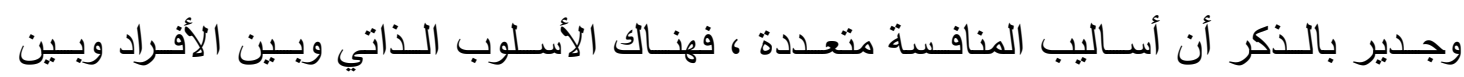

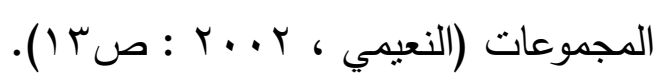

وقد أوضح "مارتنز" أن هناك أربعة مكونات تفسر المنافسة كعملية اجتماعية وهي :

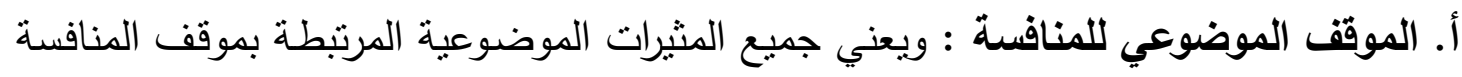

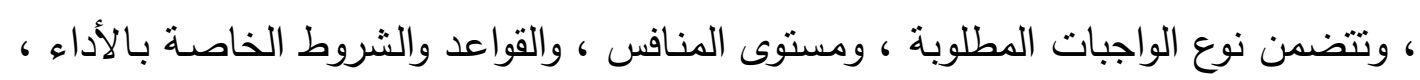

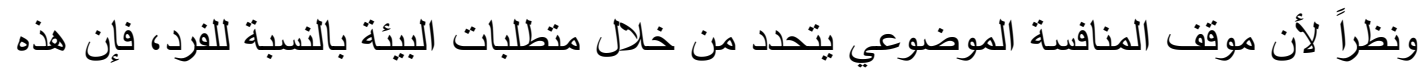

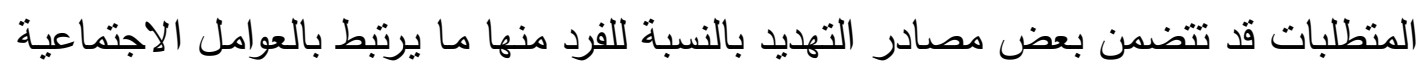

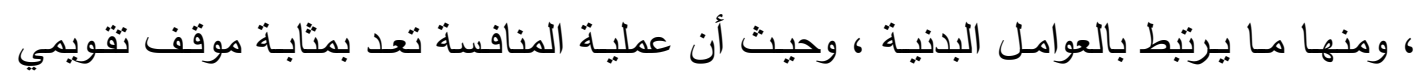

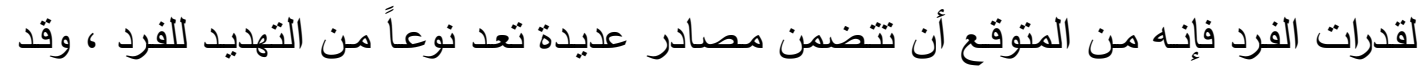

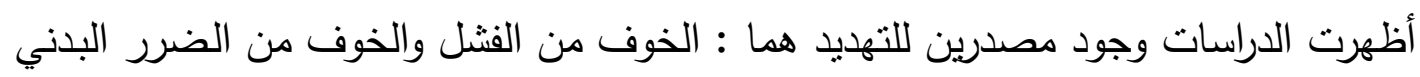

ب. الموقف الذاتي للمنافسة : يعني كيف يدرك أو ينقبل أو يقيم الفرد الجوانب الموضوعية

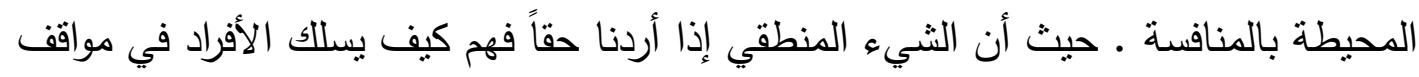

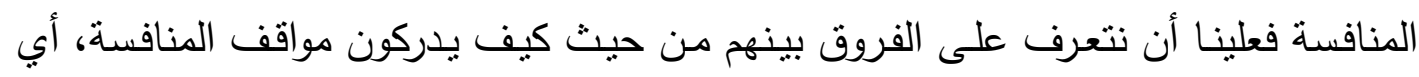
التعرف على الجانب الذاني لمواقف المنافسة كما يدركه هؤلاء الأفراد أنفسهر. 
ج. الاستجابة : تتحدد درجة استجابة الفرد نحو موقف المنافسة الموضوعي تبعاً لإدراكه الذاتي

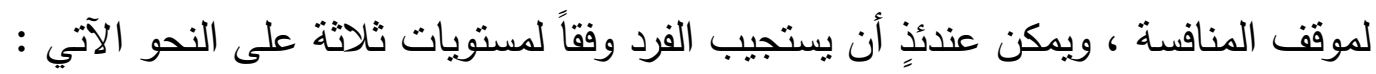

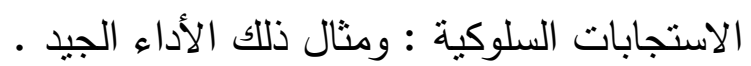

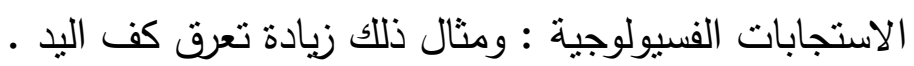

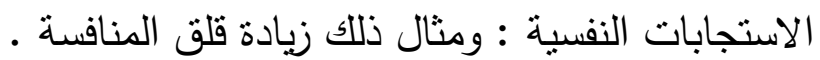

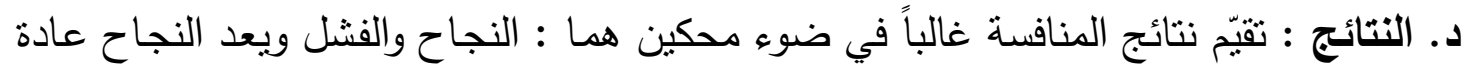

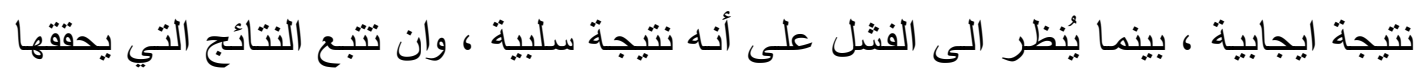

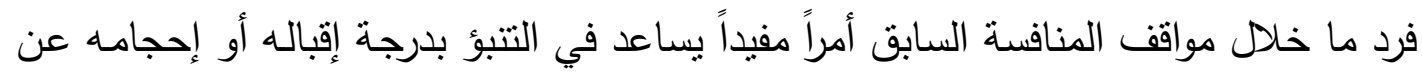

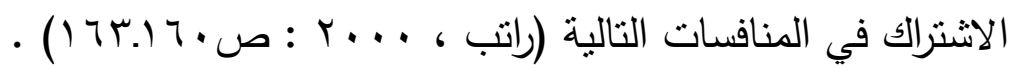

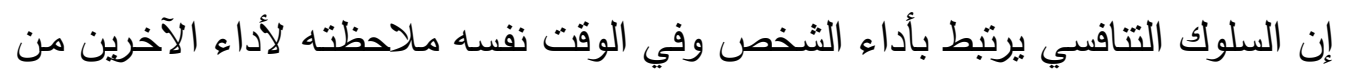

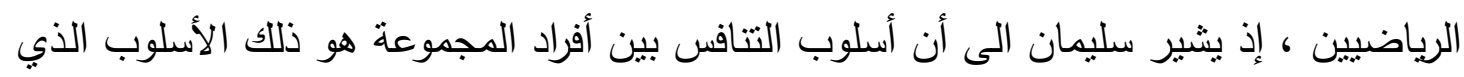

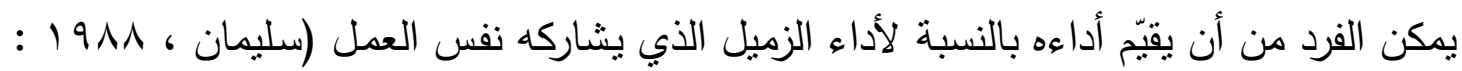

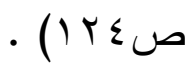
وفي المنافسة يحاول كل رياضي إحباط محاولات المنافس لنحقيق هدف ، في الوقت

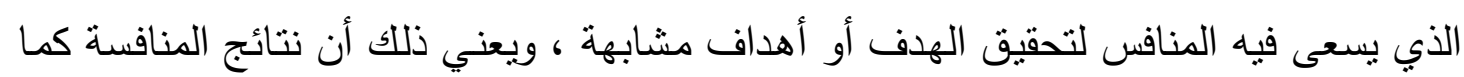

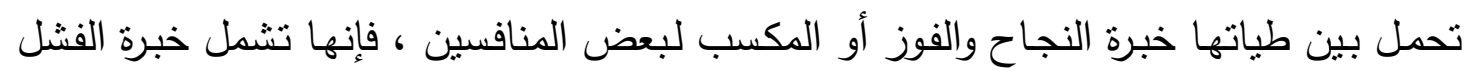

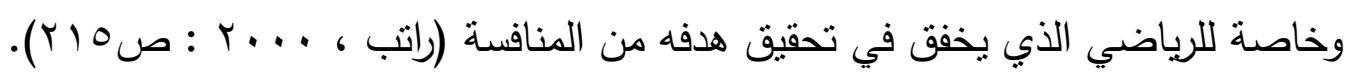

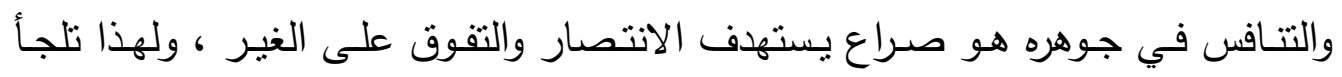

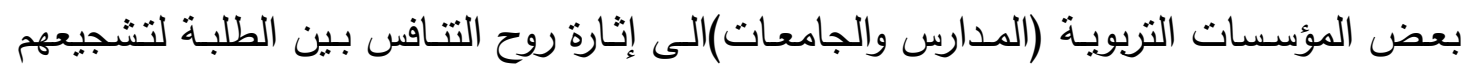

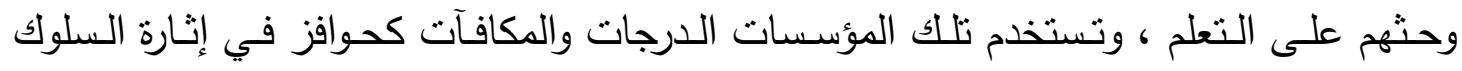

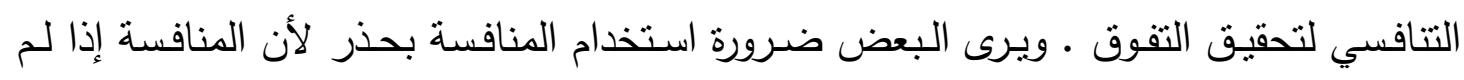

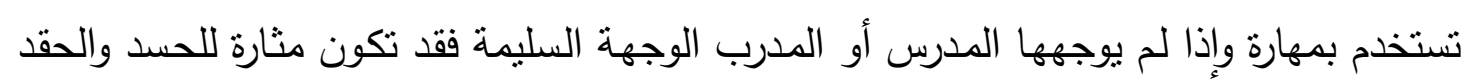

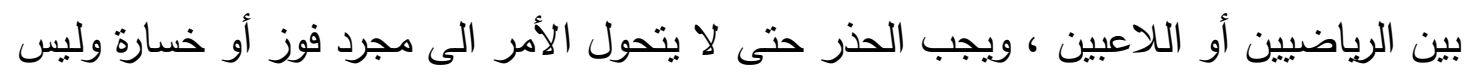

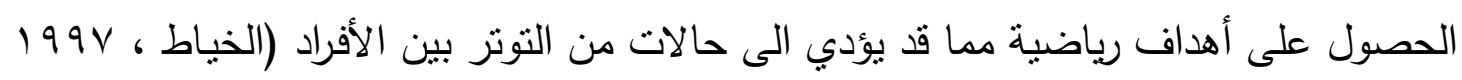

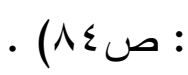

ومن هنا ينبغي على المدربين الاهتهام بسلوك التتافس لدى الرياضيين خـال فترة

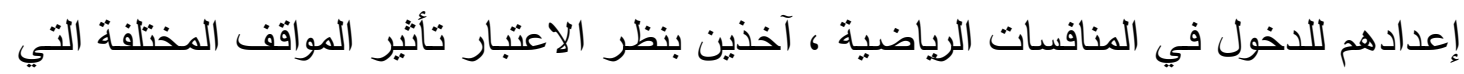

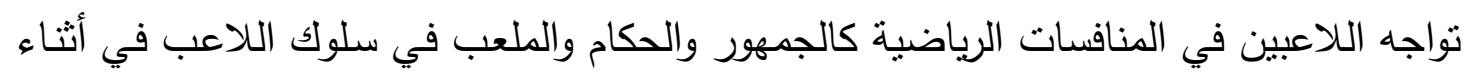

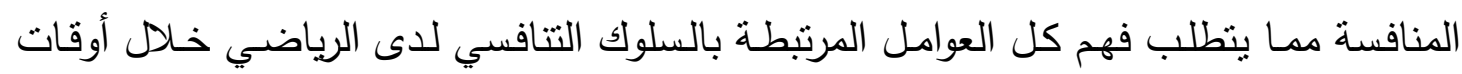

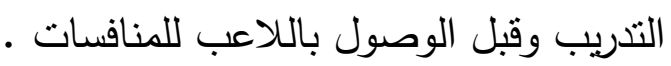


إن أهمية سلوك التنافس تكمن في وصف الطرق النفسية التي تهدف للتحكم والتغيير في سلوك اللاعب من خلال ما يقدم للرياضي من خبرات وتدريب منظم ومحاولات في مجال تعديل

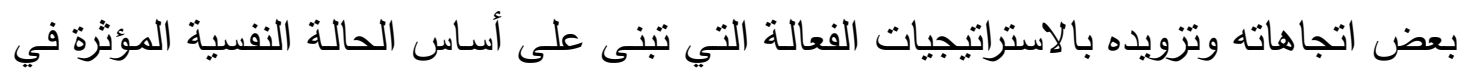

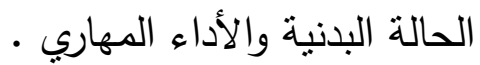

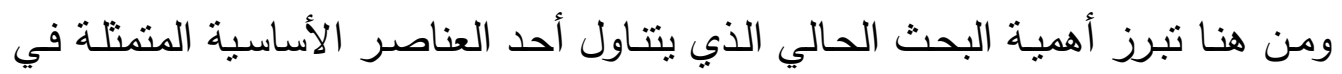

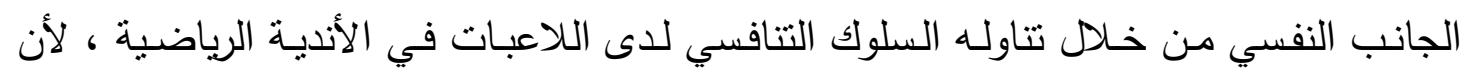

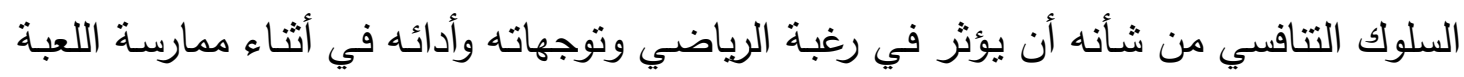

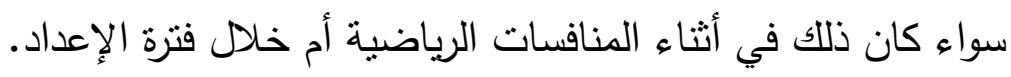

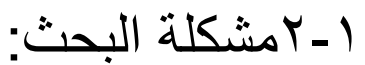

بهدف تحقيق أفضل النتائج في الأداء الرياضي حاول الباحثون دراسة العوامل المؤثرة

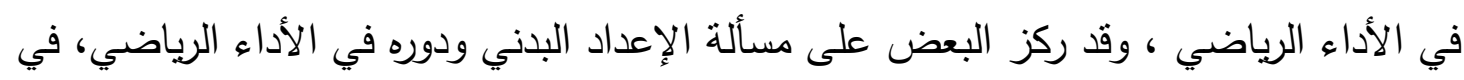

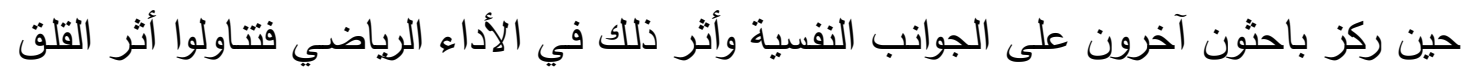

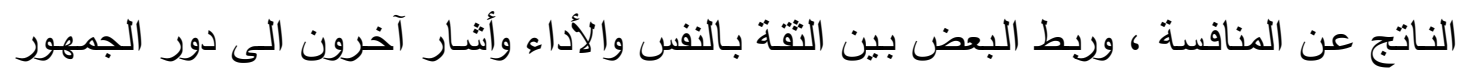

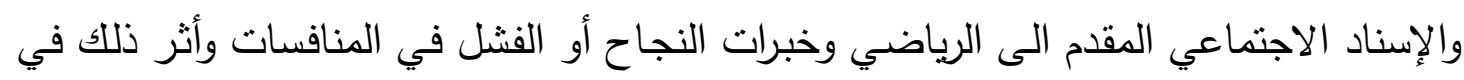

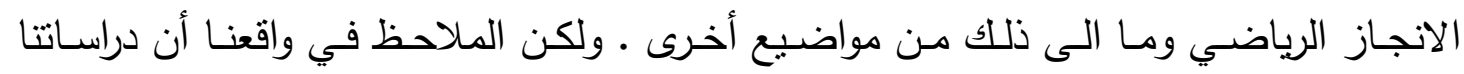

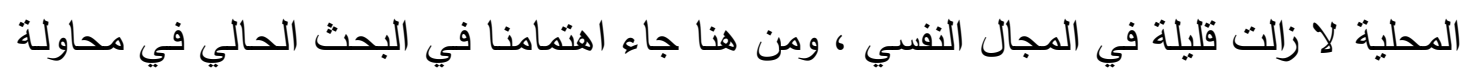

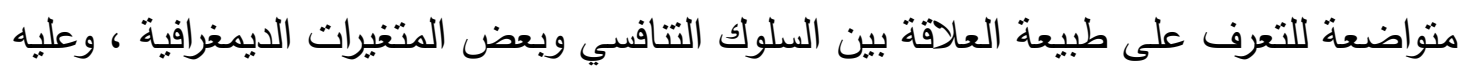
يمكن صياغة مشكلة البحث الحالي في السؤالين الآتيين:

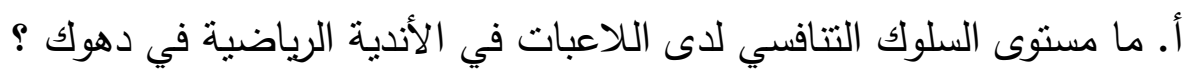

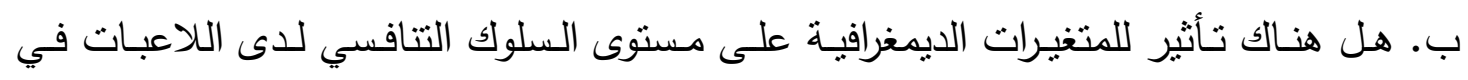

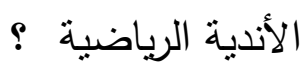

$$
\begin{aligned}
& \text { 1 أهداف البحث : }
\end{aligned}
$$

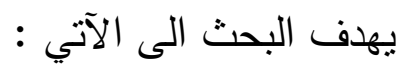

1. التعرف على مستوى السلوك التتافسي لدى اللاعبات في الأندية الرياضية .

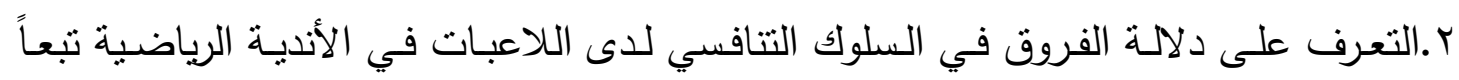

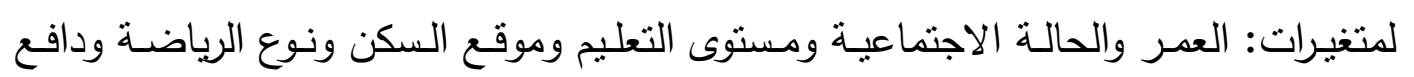
ممارسة الرياضة والحصول على الجوائز والنادي .

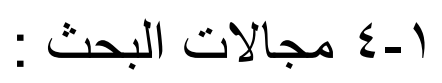

- المجال البشري : اللاعبات في الأندية الرياضية في محافظة دهوك . 


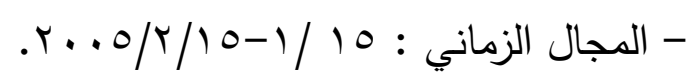

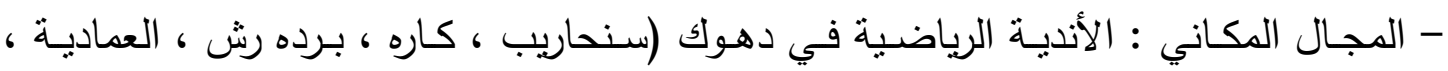

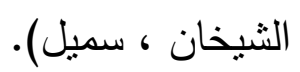

$$
\text { ـ }
$$

- السلوك : أي نشاط يرمي الى تحقيق هدف يصدر عن الإنسان استجابة للمثيرات الداخلية أو الخارجية .

- السلوك التتافسي : لقد عرف (الطالب والويس) المنافسة بأنها : " وسيلة ناجحة في استثارة

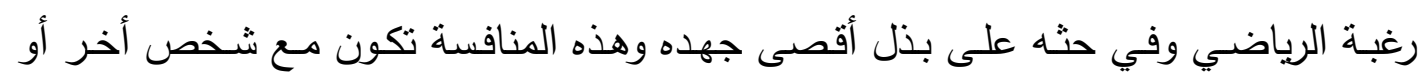

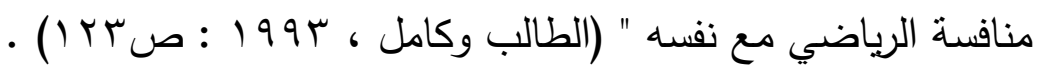

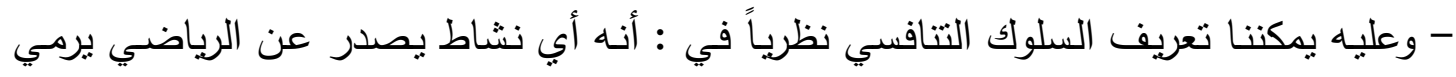

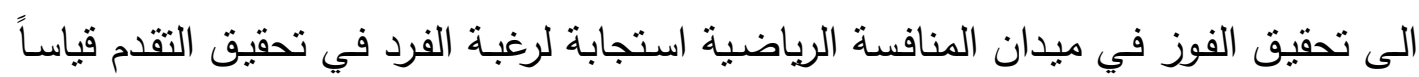

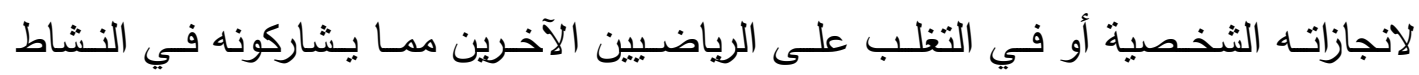
• الرباضي - ويمكن تعريفه إجرائياً لأغراض البحث الحالي في الآتي : أي نشاط يصدر عن الرياضي

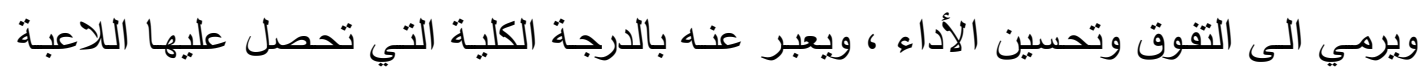

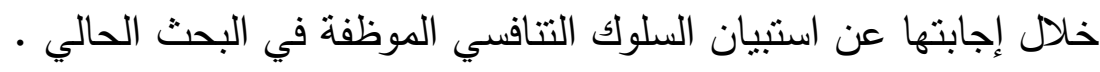

$$
\begin{aligned}
& \text { Y - منهجية البحث واجر اءاته: } \\
& \text { r - ا منهج البحث: }
\end{aligned}
$$

استخدم الباحثون المنهج الوصفي بأسلوب المسح وذلك لملائمته وطبيعة البحث .

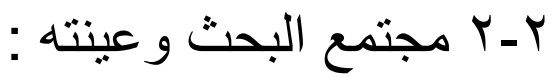

يتألف مجتمع البحث من (rو) لاعبة ممن يمارسن الألعاب الرياضية المختلفة في أندية

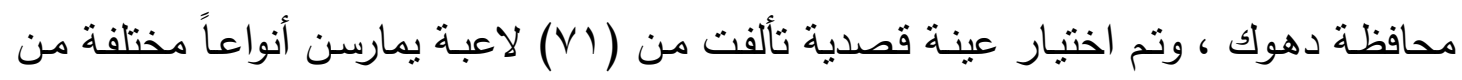

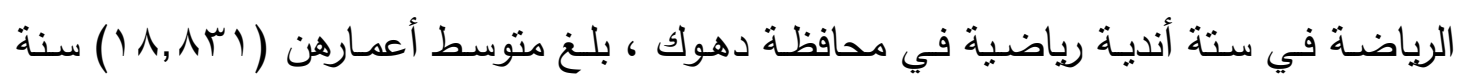

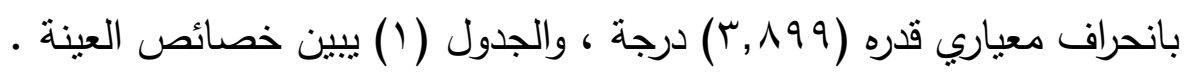




\section{الجدول (1)}

يبين الخصائص الايمغرافية لأفراد العينة

\begin{tabular}{|c|c|c|}
\hline النسبة المئوية & العدد & المتغير \\
\hline $\begin{array}{l}\% r 1.1 \\
\% r q . \varepsilon \\
\% r q .0 \\
\% 9.9\end{array}$ & $\begin{array}{l}10 \\
r 1 \\
r 1 \\
r\end{array}$ & 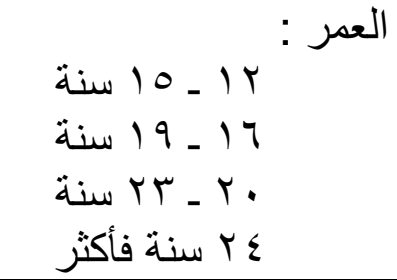 \\
\hline $\begin{array}{l}\% 9 \leq . \varepsilon \\
\% 0.7\end{array}$ & $\begin{array}{l}T V \\
\varepsilon\end{array}$ & الحالة الاجتماعية : \\
\hline $\begin{array}{l}\% \text { r. } \varepsilon \\
\% \leq 0.1 \\
\% r r .0\end{array}$ & $\begin{array}{l}\text { r } \\
\text { rt } \\
17\end{array}$ & المستوى التعليمي: \\
\hline $\begin{array}{l}\% 94 \\
\% v\end{array}$ & $\begin{array}{c}77 \\
0\end{array}$ & السكن : \\
\hline $\begin{array}{l}\% \text { \%r. } \\
\% \text { \%r. }\end{array}$ & $\begin{array}{l}r r \\
\leqslant \Lambda\end{array}$ & نوع الرياضة : فردية \\
\hline $\begin{array}{l}\% \text { \%. } \\
\% 7 . .7\end{array}$ & $\begin{array}{l}r \Lambda \\
\varepsilon r\end{array}$ & الحصول على الجوائز : \\
\hline $\begin{array}{l}\% 0.7 \\
\% \wedge 0.9 \\
\% \wedge .0\end{array}$ & $\begin{array}{l}5 \\
71 \\
7\end{array}$ & دو افع ممارسة الرياضة : هرنية \\
\hline 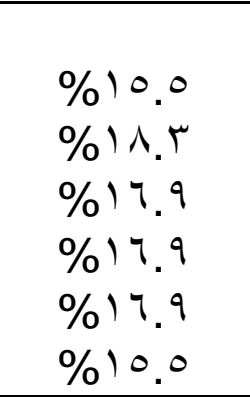 & $\begin{array}{l}11 \\
14 \\
14 \\
15 \\
14 \\
11\end{array}$ & شئن \\
\hline
\end{tabular}

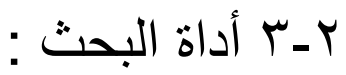

لأجل التعرف على السلوك التتافسي لدى أفراد العينة ، اعتمد الباحثون على استبيان تم إعداده لهذا الغرض من خلال الاستفادة من قائمة المنافسة الرياضية التي أعدها (رينر مارتنز) 
والمعربة من قبل محمد حسن علاوي ، وتكون الاستبيان من جزأين : خُصِصَ الجزء الأول من

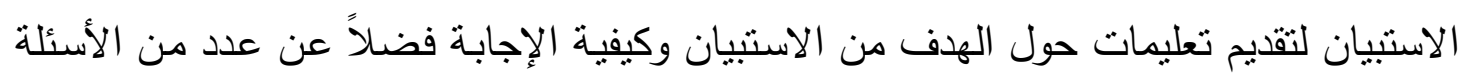

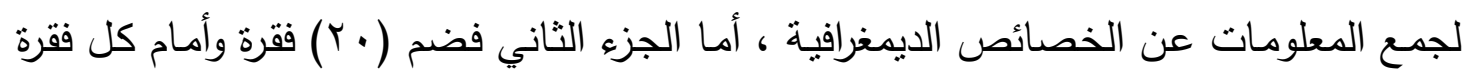

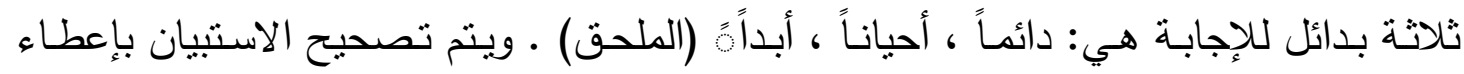

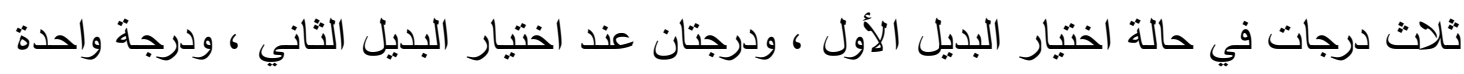

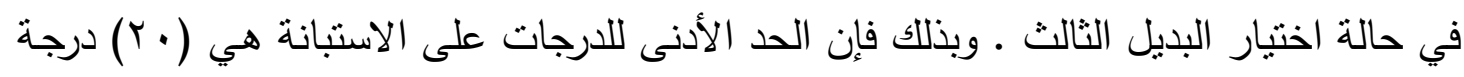

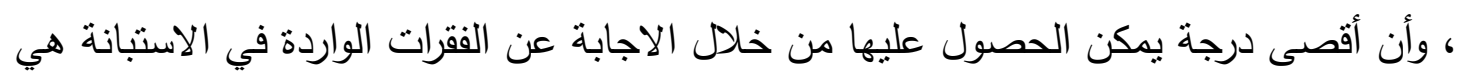

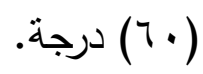

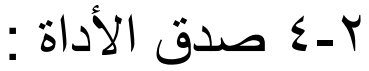

يعد الصدق من أهم الشروط الواجب توافرها في أي أداة تستخدم لأي بحث ، ويقصد

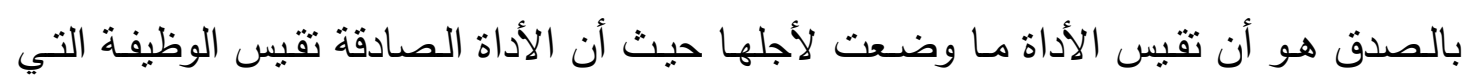

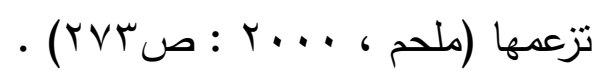

وللتحقق من صدق الأداة المستخدمة في البحث الحالي ، قام الباحثون بإيجاد الصدق الظاهري (Face Validity) وذللك بعرض الاستبيان على عدد من المتخصصين في مجال علم

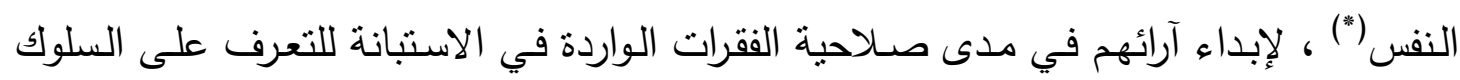

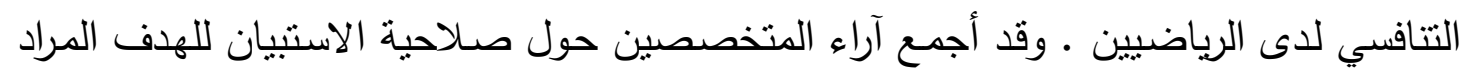

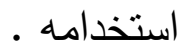

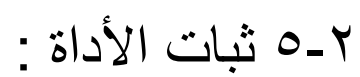

تعتمد صحة الأداة على مدى ثباتها وصدقها ، والثبات يعني دقة الأداة وعدم تتاقضها

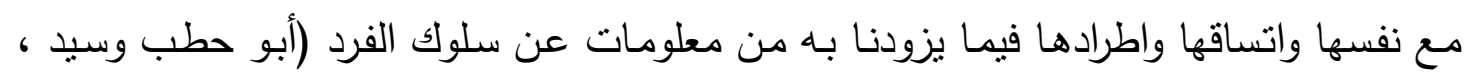
191V

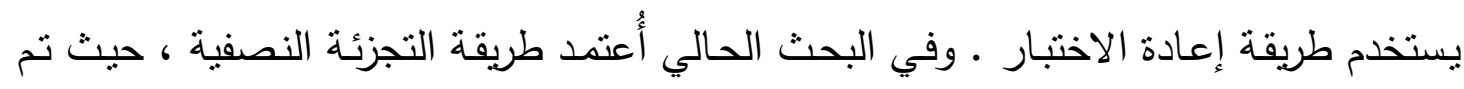

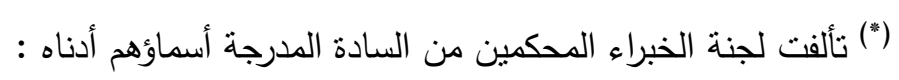

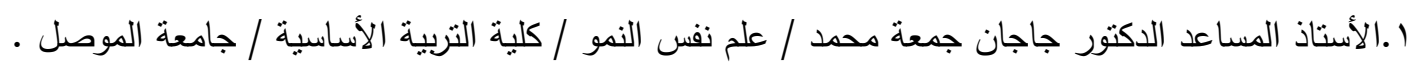

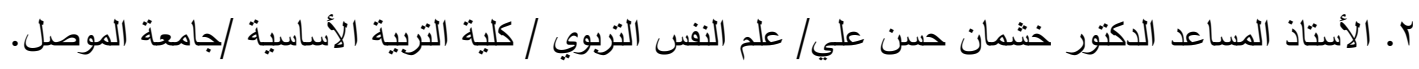

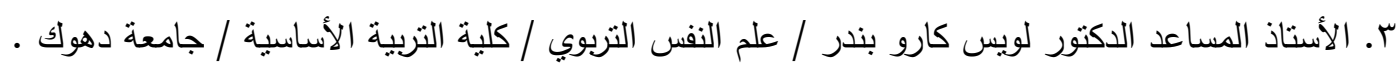

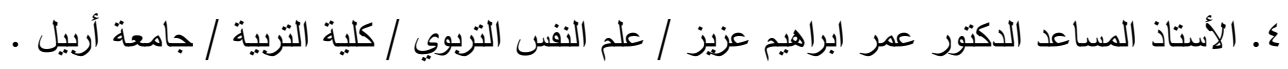

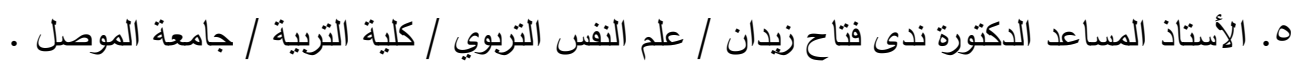


تطبيق الاستبانة على (r) ( ) لاعبة تم اختيارهن من نادي سنحاريب ، وبعد تصحيح الاستجابات

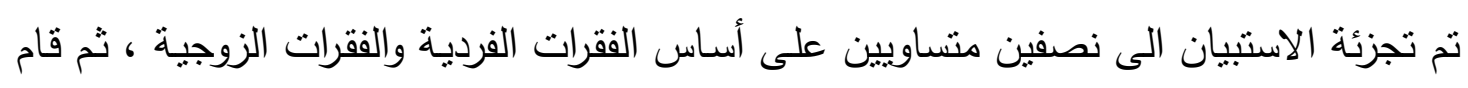

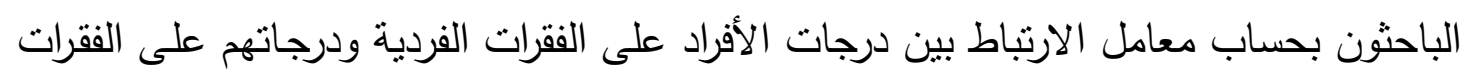

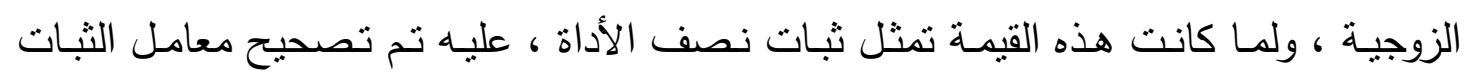

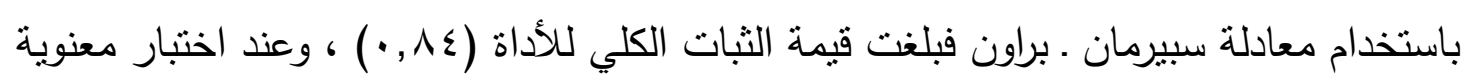

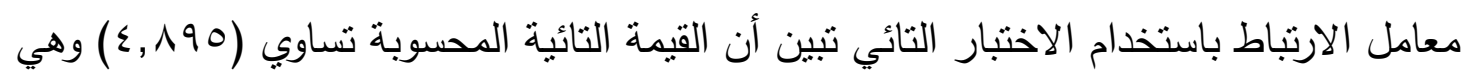

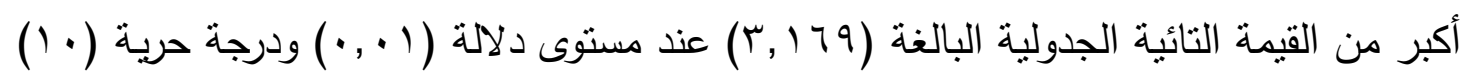

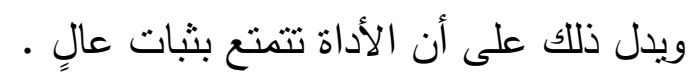

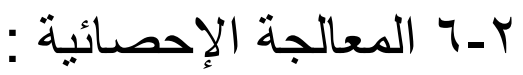

تمت معالجة البيانات إحصائياً بالاستعانة ببرنامج الحقيبة الإحصائية للعلوم الاجتماعية،

$$
\text { وباستخدام الوسائل الآتية : بالجة اليانات }
$$

ا ـ معامل ارتباط بيرسون ومعادلة سبيرمان ـ براون التصحيحية لحساب ثبات الأداة .

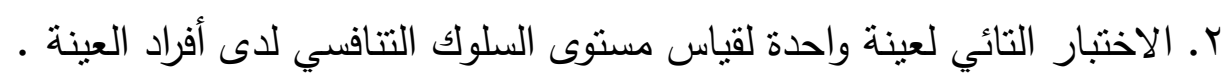

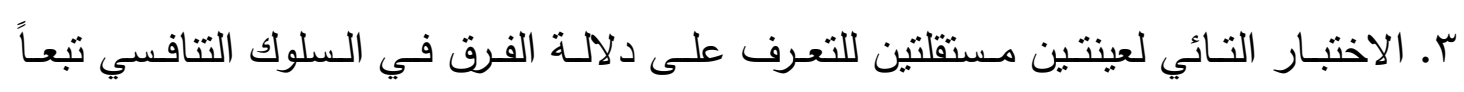

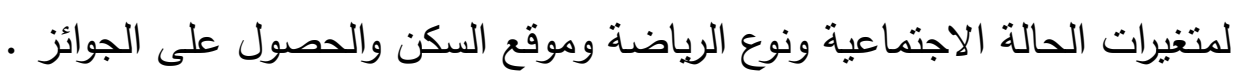

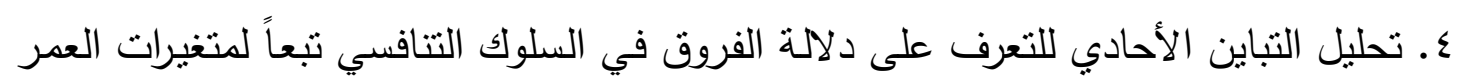
والنادي ومستوى التعليم ودوافع ممارسة الرياضة.

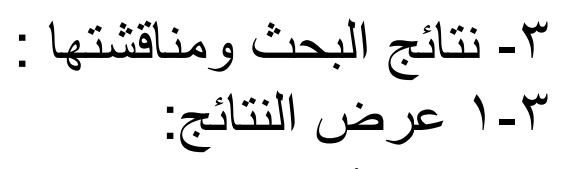

بعد أن انتهى الباحثون من تطبيق أداة البحث على أفراد العينة ، تم معالجة البيانات

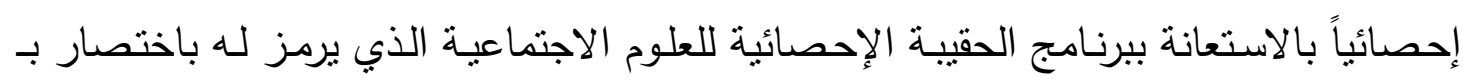
: (SPSS)

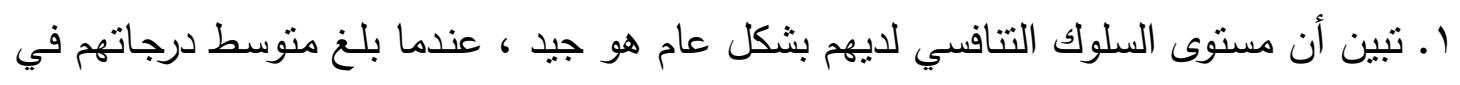

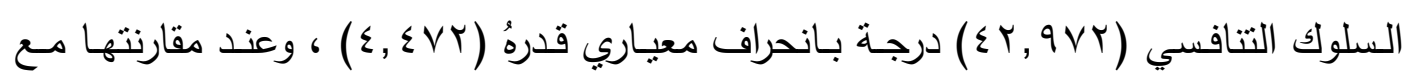

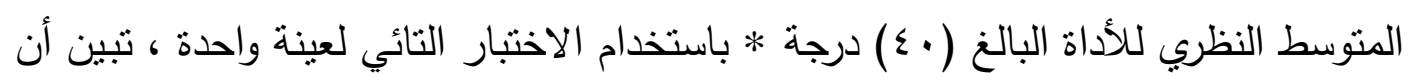

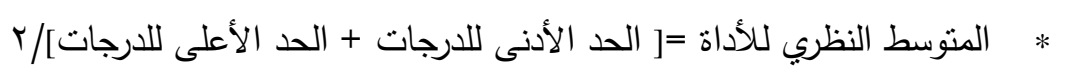

$$
\begin{aligned}
& \varepsilon \cdot=r /[r+r \cdot]=
\end{aligned}
$$




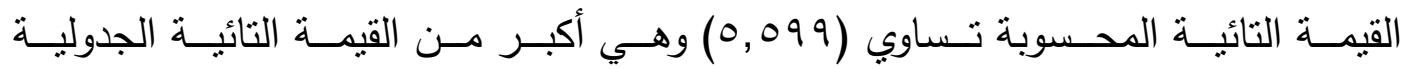

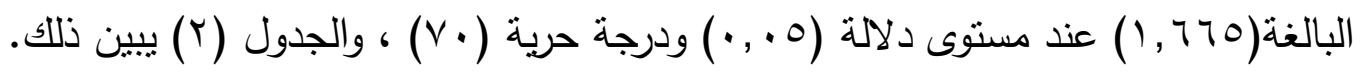

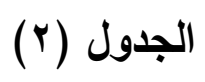

يبين دلالة الفرق باختبار " ت " بين المتوسط المتحقق والمتوسط النظري للسلوك التنافسي لأفراد العينة (ن) (V)

\begin{tabular}{|c|c|c|c|c|c|c|}
\hline \multirow{2}{*}{ مستوى الدلالة } & \multicolumn{2}{|c|}{ القيمة التائية } & \multirow{2}{*}{ النظري } & \multirow{2}{*}{ الانحراف } & \multirow{2}{*}{ المتحقق } & \multirow{2}{*}{ المتغير } \\
\hline & الجدولية & المحسوية & & & & \\
\hline$\cdot, .0$ & 1,770 & 0,099 & $\varepsilon$. & $\varepsilon, \Sigma V Y$ & $\varepsilon r, q \vee r$ & السلوكي \\
\hline
\end{tabular}

r. ولأجل التعرف على دلالة الفروق في السلوك التنافسي تبعاً لمتغير العمر ، فقد نم توزيع أفراد

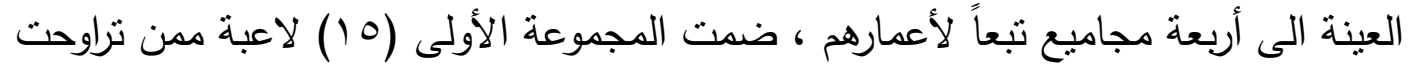

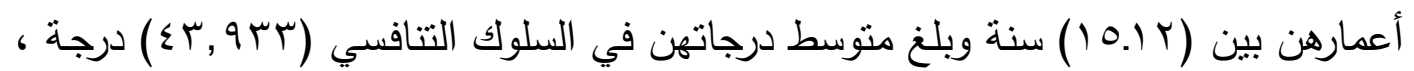

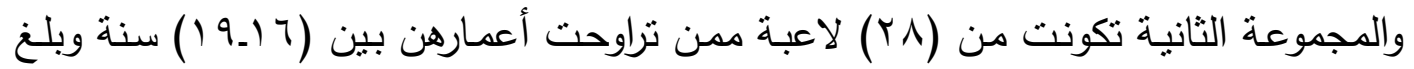

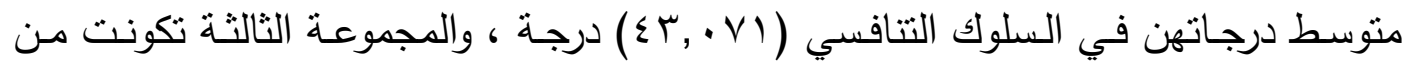

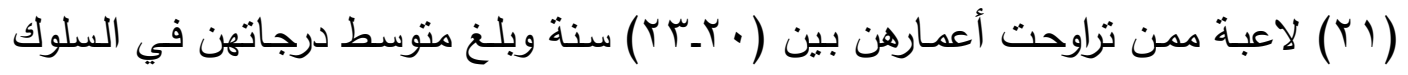

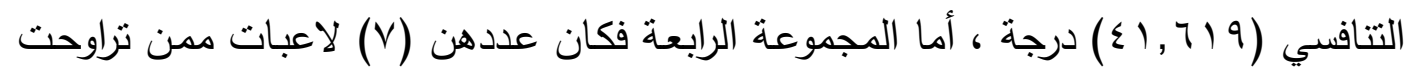

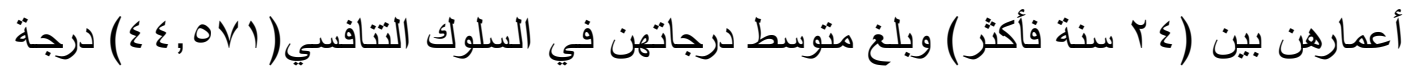

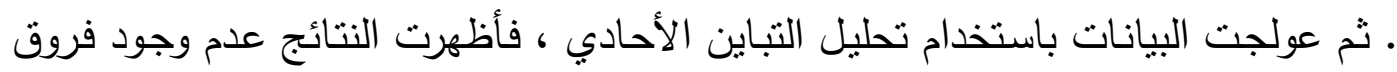

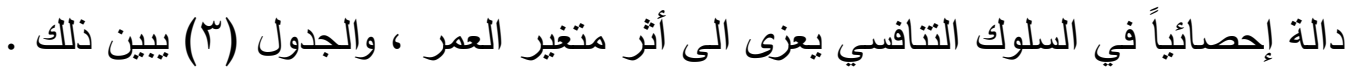

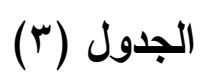

\begin{tabular}{|c|c|c|c|c|c|c|}
\hline \multirow{2}{*}{ مستوى الدلاكة } & \multicolumn{2}{|c|}{ القيمة الفائية } & \multirow{2}{*}{ المربعات } & \multirow{2}{*}{ الحرية } & \multirow{2}{*}{ المريعات } & \multirow{2}{*}{ مصدر التباين } \\
\hline & الجدولية & المحسوية & & & & \\
\hline \multirow{3}{*}{ غير دال } & \multirow[t]{3}{*}{ Y,VT } & \multirow[t]{3}{*}{$1,1 \wedge \varepsilon$} & $Y T, \sum 9 T$ & r & $V_{\cdot},\{\wedge \vee$ & بين المجوعات \\
\hline & & & $19, \wedge \leqslant r$ & TV & $1 r r q, \varepsilon 0 V$ & داخل المجموعات \\
\hline & & & & $v \cdot$ & $1499,9 \leq \varepsilon$ & الكلي \\
\hline
\end{tabular}

يبين نتائج تحليل التباين الأحادي لالالة الفرق في السلوك التنافسي تبعاً لمتغير العمر

وللكثف عن دلالة الفروف في السلوك التتافسي تبعاً لمتغير الحالة الاجتماعية ، فقد تم

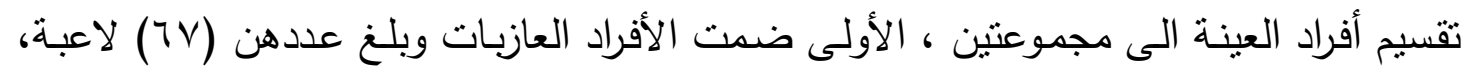


والثانيـة تألفت من (ع) لاعبات من المتزوجات ، وعند إجراء المقارنـة بين منوسطي درجات

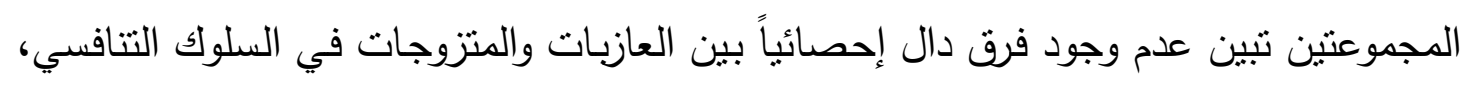
والجدول (ع) يبين ذلك .

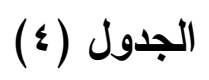

يبين دلالة الفرق باختبار " ت " في السلوك التنافسي تبعاً لمتغير الحالة الاجتماعية

\begin{tabular}{|c|c|c|c|c|c|c|}
\hline \multirow{2}{*}{ مستوى الدلالة } & \multicolumn{2}{|c|}{ القيمة التائية } & \multirow{2}{*}{ الانحراف } & \multirow{2}{*}{ الصسابي } & \multirow{2}{*}{ العدد } & \multirow{2}{*}{ الاجتماعية الحالة } \\
\hline & الجدولية & المحسوية & & & & \\
\hline \multirow{2}{*}{ غير دال } & \multirow[t]{2}{*}{$r, \ldots$} & \multirow[t]{2}{*}{$\cdot, \sum V \mid$} & $\leqslant, 0 \leqslant \Lambda$ & $\{r, q)$. & TV & أعزب \\
\hline & & & $r, 17 r$ & $\varepsilon \varepsilon, \ldots$ & $\varepsilon$ & متزوج \\
\hline
\end{tabular}

ولأجل معرفـة أثر المستوى التعليمي في السلوك التتافسي لدى اللاعبات في الأنديـة

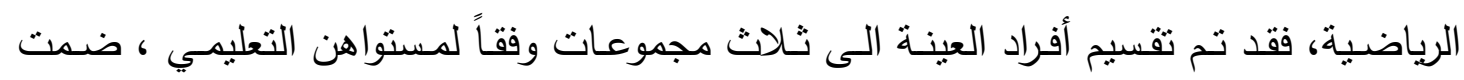
المجموعة الأولى (Yr) لاعبة في مستوى الدراسة المتوسطة وبلغ متوسط درجاتهن في السلوك

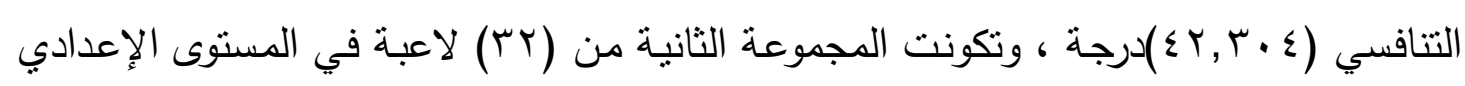

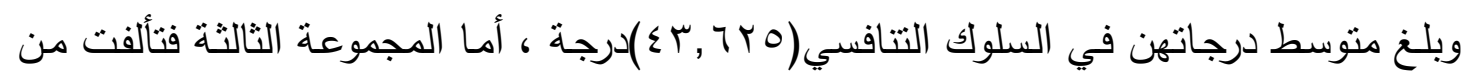

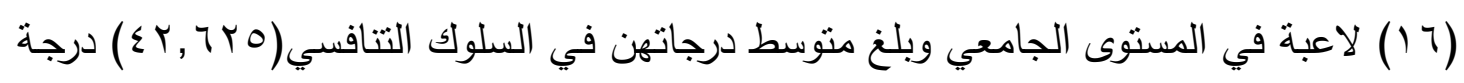
• وعند إجراء المقارنة بين المجموعات الثلاث باستخدام تحليل التباين الأحادي وسيلة إحصائية

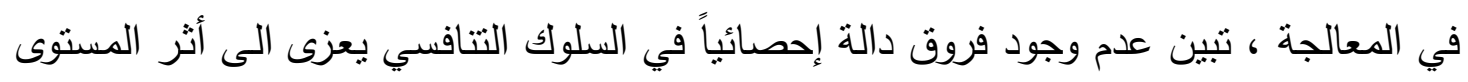

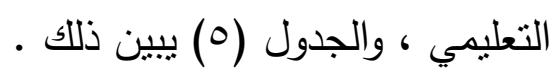

(0) (الجدول

\begin{tabular}{|c|c|c|c|c|c|c|}
\hline \multirow{2}{*}{ مستوى الدلالة } & \multicolumn{2}{|c|}{ القيمة الفائية } & \multirow{2}{*}{ المريعات } & \multirow{2}{*}{ الحرجية } & \multirow{2}{*}{ المربعات } & \multirow{2}{*}{ مصدر التباين } \\
\hline & الجدولية & المحسوية & & & & \\
\hline \multirow{3}{*}{ غير دال } & \multirow[t]{3}{*}{$r, 10$} & \multirow[t]{3}{*}{ 9 } & $|r, q| r$ & r & ro,AY & بين المجوعات \\
\hline & & & $r \cdot, r \cdot \Lambda$ & 71 & $M \leqslant V, I T$. & داخل المجموعات \\
\hline & & & & V. & $1 \% q 9,9 \leq \varepsilon$ & الكلي \\
\hline
\end{tabular}

ولمعرفة أثر موقع السكن في السلوك التتافسي ، تم تقسيم أفراد العينة الى مجموعتين

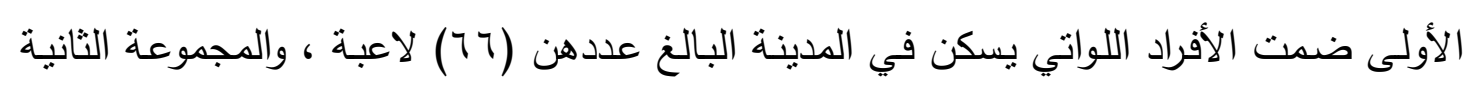

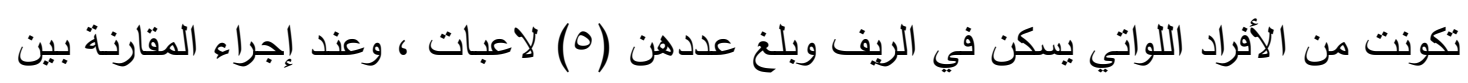


متوسطي درجات المجموعتين باستخدام الاختبار التائي لعينتين مستقلتين ، تبين عدم وجود فرق

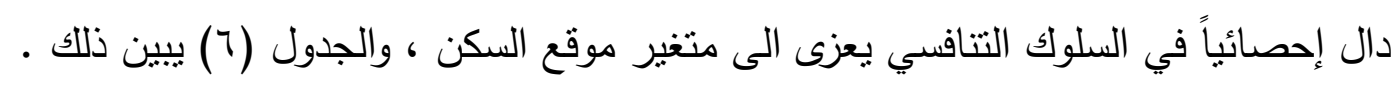

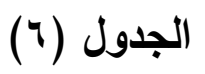

يبين دلالة الفرق باختبار " ت " في السلوك التنافسي تبعاً لمتغير موقع السكن

\begin{tabular}{|c|c|c|c|c|c|c|}
\hline \multirow{2}{*}{ مستوى الدلالة } & \multicolumn{2}{|c|}{ القيمة التائية } & \multirow{2}{*}{ الالمعياري } & \multirow{2}{*}{ الحسابي } & \multirow{2}{*}{ العدد الع } & \multirow{2}{*}{ موقع } \\
\hline & الجدولية & المحسوية & & & & \\
\hline \multirow{2}{*}{ غند 0 ., •. } & \multirow[t]{2}{*}{$r, \ldots$} & \multirow[t]{2}{*}{$1, \vee \vee 0$} & $\varepsilon, 0.9$ & $\varepsilon r, r Y V$ & 77 & المدينة \\
\hline & & & $r, \cdot V \varepsilon$ & $r q, 7 \ldots$ & 0 & الريف \\
\hline
\end{tabular}

وللكثف عن دلالة الفروق في السلوك التتافسي تبعاً لمتغير نوع الرياضة التي تمارسها

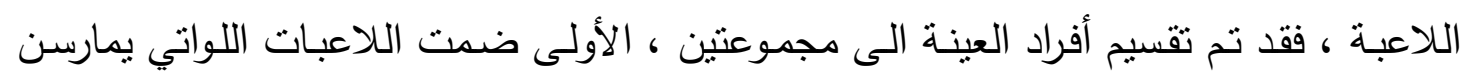

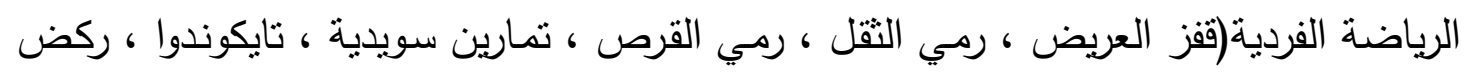

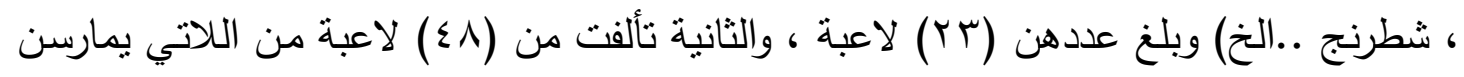

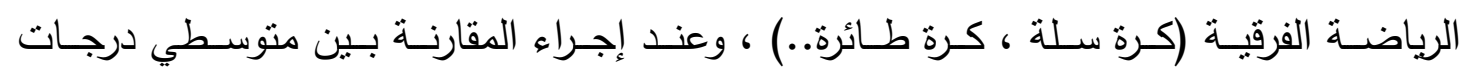

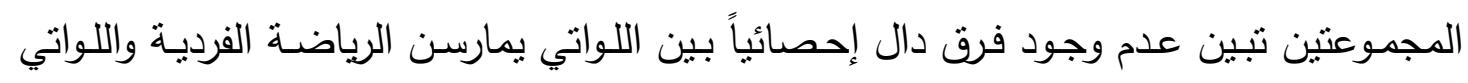

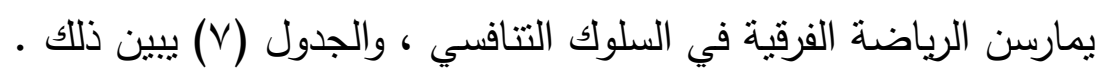

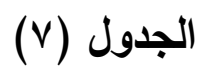

يبين دلالة الفرق باختبار " ت " في السلوك التنافسي تبعاً لمتغير نوع الرياضة

\begin{tabular}{|c|c|c|c|c|c|c|}
\hline \multirow{2}{*}{ مستوى الدلاية } & \multicolumn{2}{|c|}{ القيمة التائية } & \multirow{2}{*}{ الانحراف } & \multirow{2}{*}{ المسابي } & \multirow{2}{*}{ العدد } & \multirow{2}{*}{ الرياضة } \\
\hline & الجدولية & المحسوية & & & & \\
\hline \multirow{2}{*}{ غند هير دال . } & \multirow[t]{2}{*}{$r, \ldots$} & \multirow[t]{2}{*}{$\cdot, \leqslant \vee \backslash$} & $r, 1 \mu$. & $\leq r, 7, q$ & rT & فردية \\
\hline & & & $0, \cdot 11$ & $\leq r, 1 \leq T$ & $\varepsilon \wedge$ & فرقية \\
\hline
\end{tabular}

ولأجل معرفة أثز الحصول على الجوائز في السلوك التتافسي لدى اللاعبات في الأندية

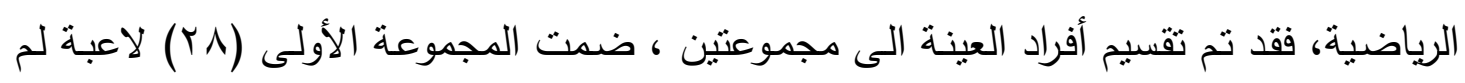

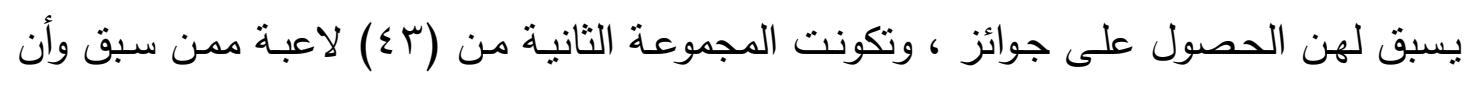

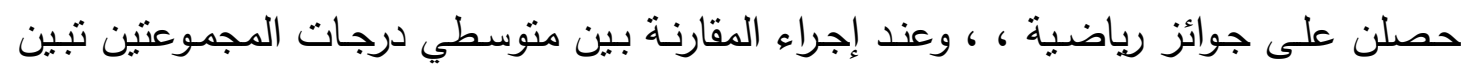

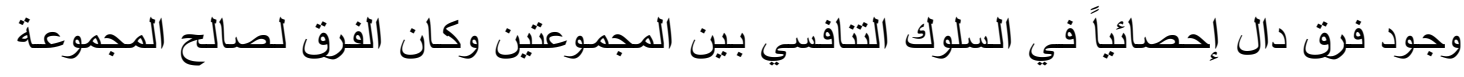

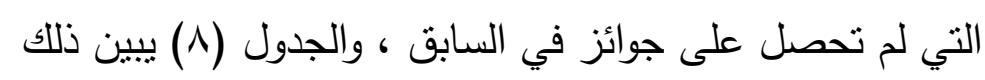

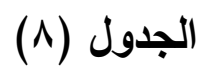

يبين دلالة الفرق باختبار " ث " في السلوك التنافسي تبعاً لمتغير الحصول على الجوائز 


\begin{tabular}{|c|c|c|c|c|c|c|}
\hline \multirow{2}{*}{ مستوى } & \multicolumn{2}{|c|}{ القيمة التائية } & \multirow{2}{*}{ الانحراف } & \multirow{2}{*}{ المتوبط الحسابي } & \multirow{2}{*}{ العدد } & \multirow{2}{*}{ الحصول } \\
\hline & الجدولية & المحسوية & & & & \\
\hline \multirow[t]{2}{*}{., .0} & \multirow[t]{2}{*}{$r, \ldots$} & \multirow[t]{2}{*}{ T,YYV } & $\varepsilon, 1 T r$ & $\leqslant \leqslant, 97 \leqslant$ & rᄉ & $y$ \\
\hline & & & $\varepsilon, Y \leq 1$ & $\varepsilon 1,7 \vee \varepsilon$ & $\varepsilon r$ & نعم \\
\hline
\end{tabular}

ولأجل معرفة أثز النادي في السلوك التنافسي لدى اللاعبات في الأندية الرياضية، فقد تم

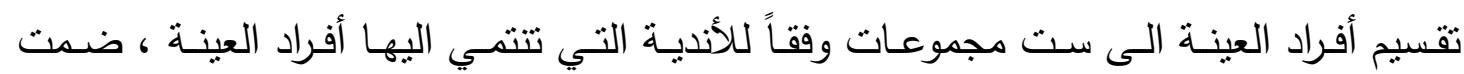
المجموعـة الأولى (1) (1) لاعبـة في نـادي سميل وبلـغ متوسـ درجاتهن في السلوك التتافسي

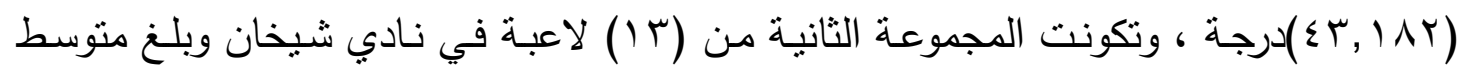

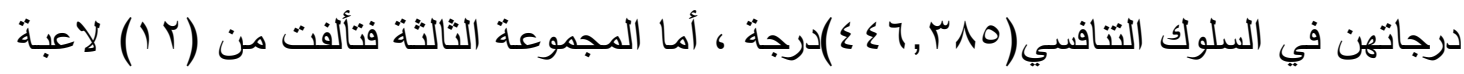

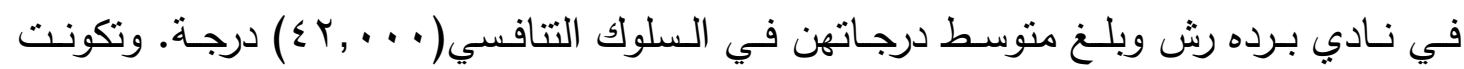
المجموعة الرابعة من (Y I) لاعبـة في نـادي كاره وبلـغ متوسط درجاتهن في السلوك التتافسي

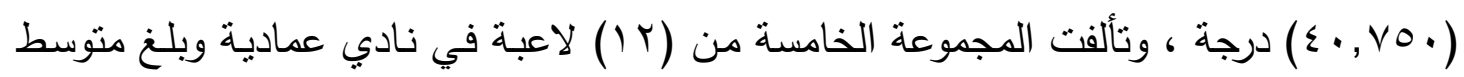

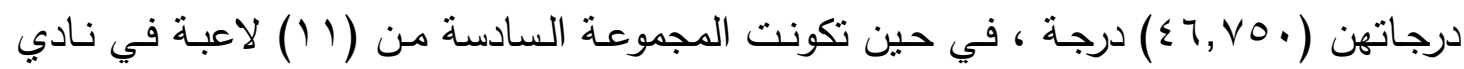

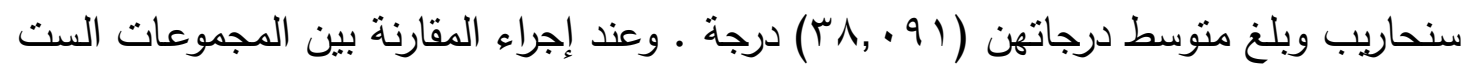
باستخدام تحليل التباين الأحادي وسيلة إحصائية في المعالجة ، تبين وجود فروق دالة إحصائياً في السلوك التنافسي يعزى الى أثز المستوى التعليمي ، والجدول (9) يبين ذلك .

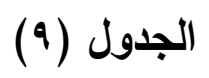

يبين نتائج تحليل التباين الأحادي لالالة الفرق في السلوك التنافسي تبعاً لمتغير التادي

\begin{tabular}{|c|c|c|c|c|c|c|}
\hline \multirow{2}{*}{ الدلاكة } & \multicolumn{2}{|c|}{ القيمة الفائية } & \multirow{2}{*}{ متوبط المربعات } & \multirow{2}{*}{ الحرية } & \multirow{2}{*}{ المربعات } & \multirow{2}{*}{ مصدر التباين } \\
\hline & الجدولية & المحسوبة & & & & \\
\hline \multirow[t]{3}{*}{$\cdot, \cdot 0$} & \multirow[t]{3}{*}{$r, r V$} & \multirow[t]{3}{*}{$11, \leqslant 0 V$} & $11,17 \varepsilon$ & 0 & $700, \wedge Y_{1}$ & بين المجوعات \\
\hline & & & $11, \leq \leqslant 1$ & 70 & $V \varepsilon \varepsilon, 1 Y r$ & داخل المجموعات \\
\hline & & & & V. & $1 \% q 9,9 \leq \varepsilon$ & الكلي \\
\hline
\end{tabular}

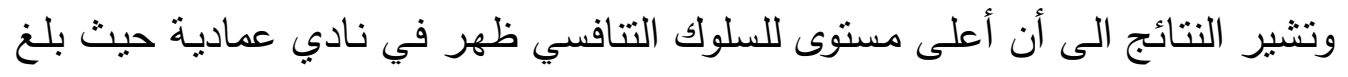

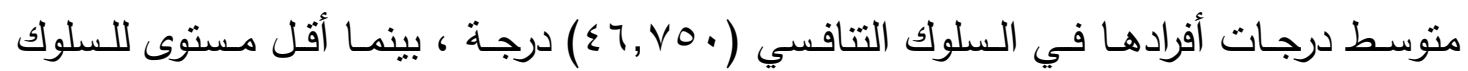

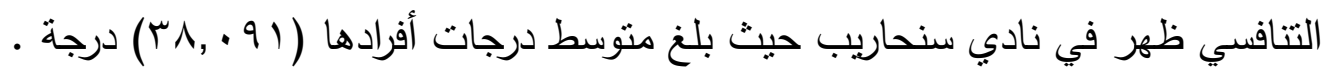


ولأجل معرفة أثز الدافع لممارسة الرياضة في السلوك التتافسي لدى اللاعبات في الأندية

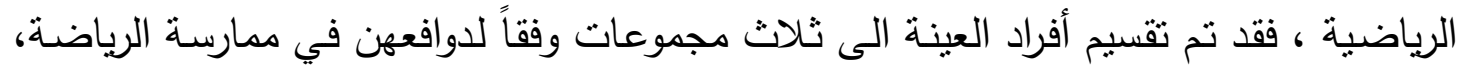

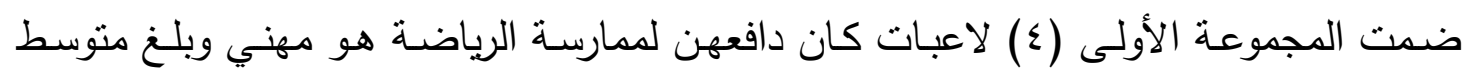

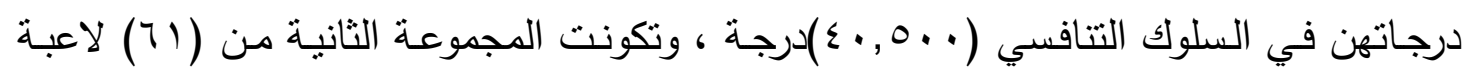

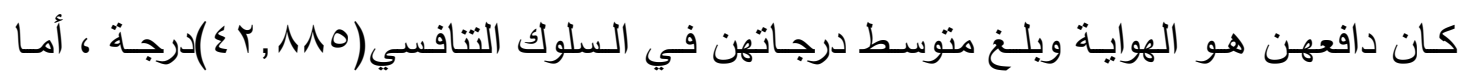

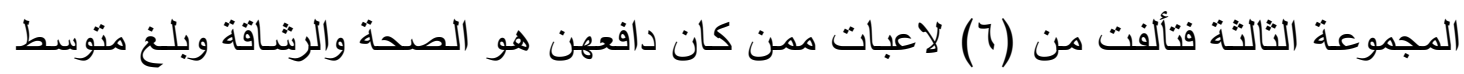

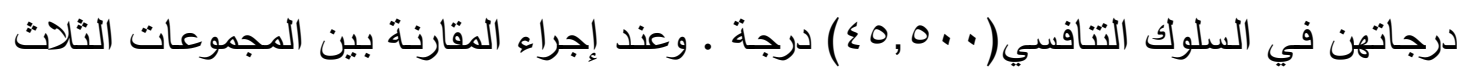

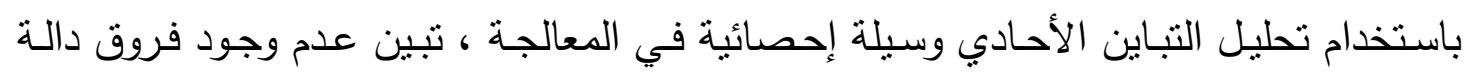

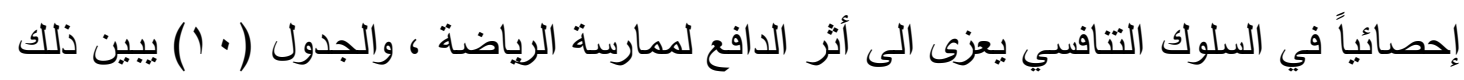

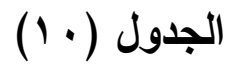

يبين نتائج تحليل التباين الأحادي لدلالة الفرق في السلوك التتافسي تبعاً لمتغير الافافع لممارسة الرياضة

\begin{tabular}{|c|c|c|c|c|c|c|}
\hline \multirow{2}{*}{ مستوى الدلاكة } & \multicolumn{2}{|c|}{ القيمة الفائية } & \multirow{2}{*}{ المريعات } & \multirow{2}{*}{ الحرجية } & \multirow{2}{*}{ المربعات } & \multirow{2}{*}{ مصدر التباين } \\
\hline & الجدولية & المحسوية & & & & \\
\hline \multirow{3}{*}{ غير دال } & \multirow[t]{3}{*}{$r, 10$} & \multirow[t]{3}{*}{$1,7.9$} & TrT, וT & r & $T r, Y \leq V$ & بين المجوعات \\
\hline & & & $19,70 \mathrm{~V}$ & 71 & ITr4,79V & داخل المجموعات \\
\hline & & & & v. & $1499,9 \leq \varepsilon$ & الكلي \\
\hline
\end{tabular}

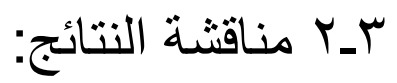

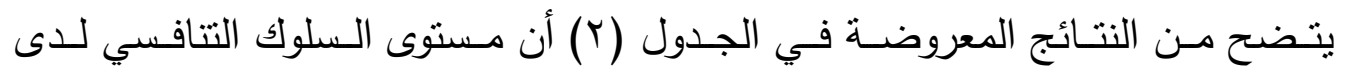
اللاعبات في الأندية الرياضية هو جيد ـ ويمكن تفسير هذه النتيجة في أن عدد اللواتي يمارسن

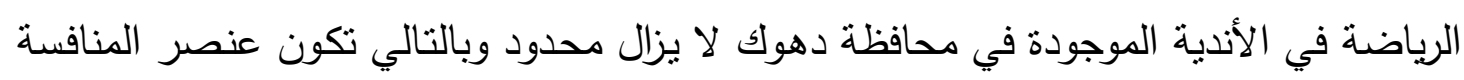

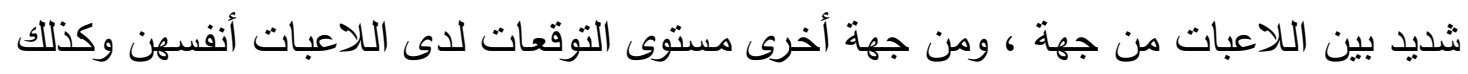

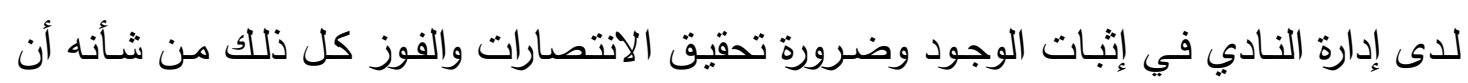

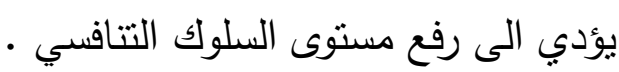

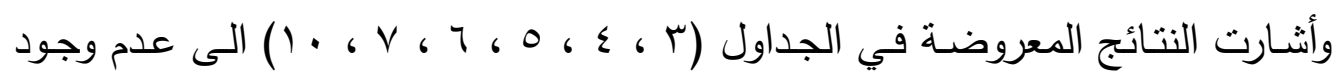

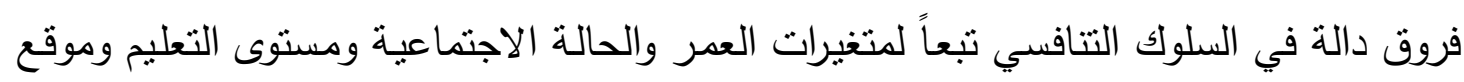

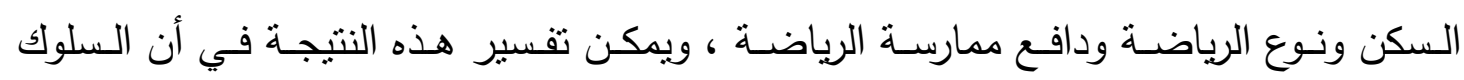
التتافسي لا يرتبط بعامل العمر ذلك لأن في كل الأعمار هناك منافسة من أجل تحقيق الكياض الذات 
والوصـول الى الفوز ، كمـا أن السلوك التتافسي لا يرتبط بالحالـة الاجتماعيـة ذلك لأن الفتاة العازبة وكذلك المرأة المنزوجة عند ممارستها للأنثطة الرياضية تبغي الوصول الى تحقيق نتائج

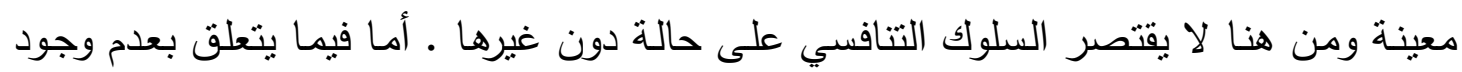

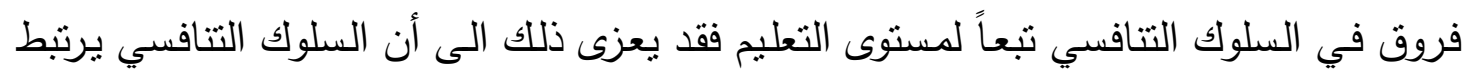

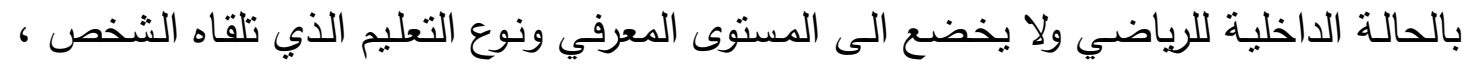

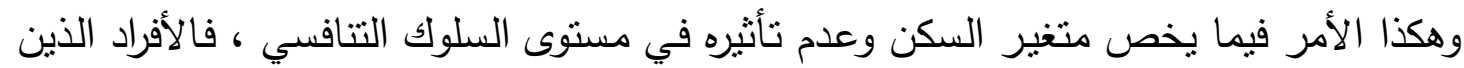

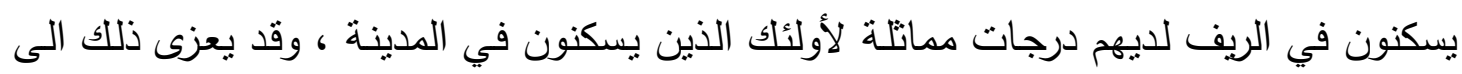

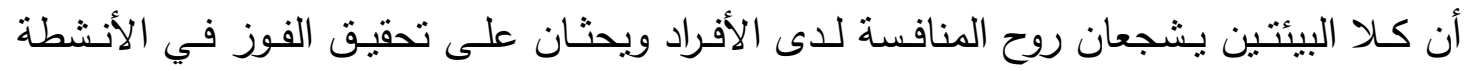

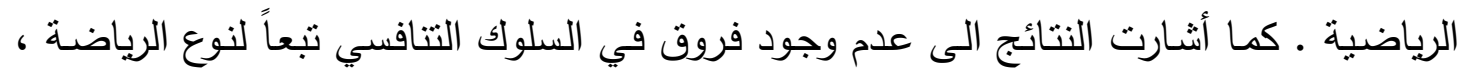
وقد يعزى ذلك الى أن أي نشاط رياضي يمارسه الفرد يهدف الى تطوير قدرات الفرد ومهاراته

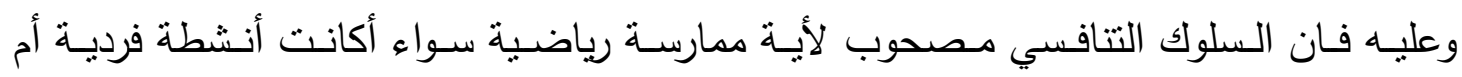
ممارسات على مستوى فرق وألعاب جماعية ، فهناك التتافس الذاتي حيث يقوم الفرد بمقارنة لافية

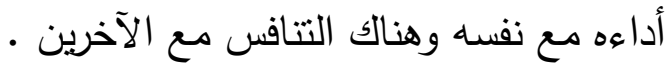
وفضلاً عما تقدم فقد أثنارت النتائج الى عدم وجود فرق دال في السئ السلوك التتافسي تبعاً

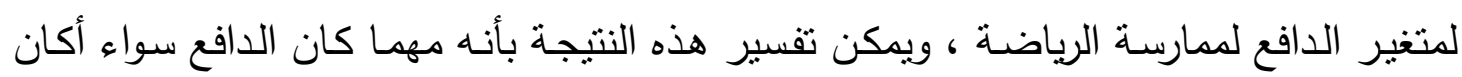

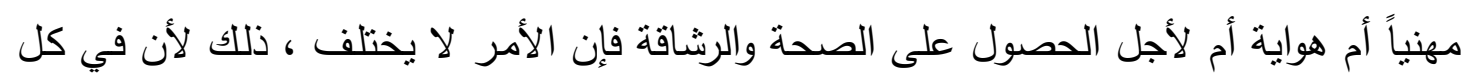

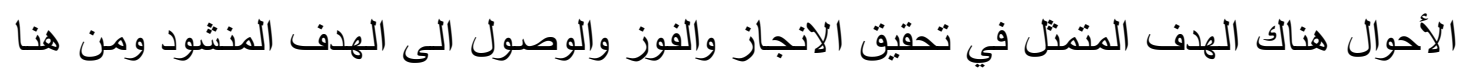

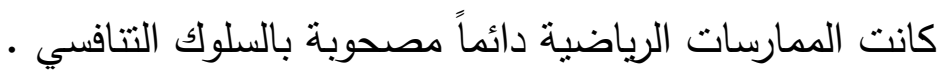

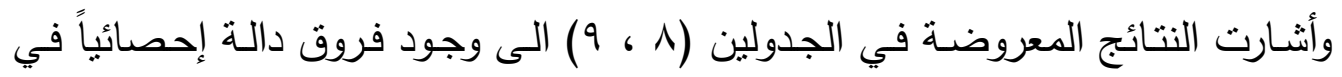

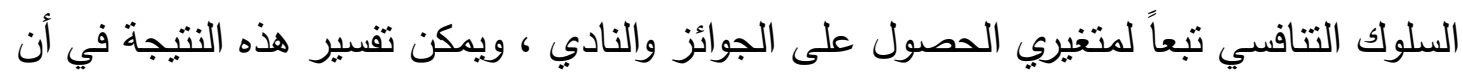

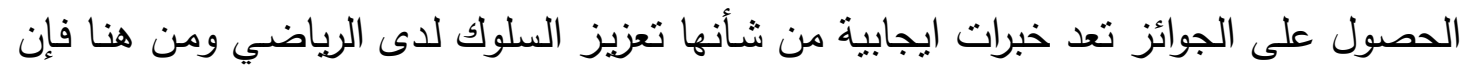

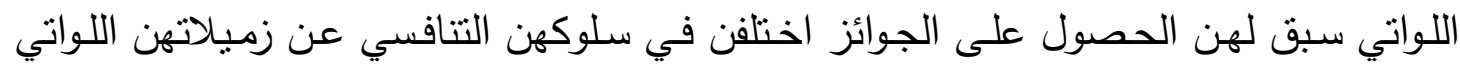

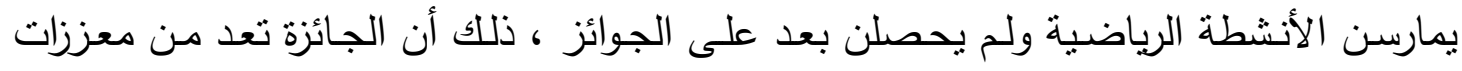

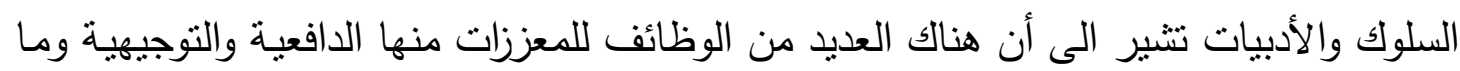

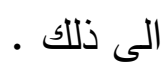

وأخيراً ، أثنارت النتائج الى وجود تباين في السلوك التتافسي لدى أفراد العينة تبعاً للتغير

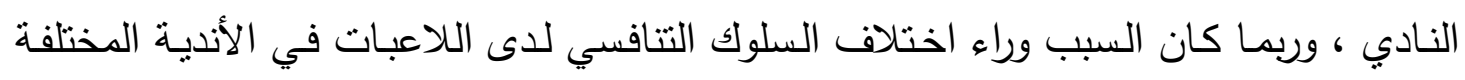
يعود الى اختلاف تلك الأندية في امكانياتها وطبيعة الادارة الموجودة في كل نادي وكذللك ما ولان تحظى بها كل لاعبة في النادي من اهتمام وتتجيع • 


\section{ع - الاستنتاجات و التوصيات :

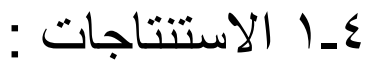

من خلال ما تقدم من نتائج توصل اليها البحث الحالي يمكن أن نستتتج الآتي :

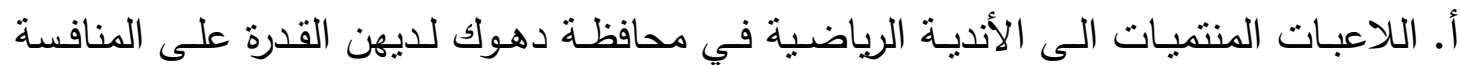

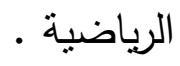

ب. إن ارتفاع مستوى السلوك النتافسي يستوجب الاهتمام بالجانب النفسي في الإعداد الرياضي لللاعبات في الأندية لكي لا يؤثر المستوى العالي من سلوك المنافسة بشكل سلبي في أداء

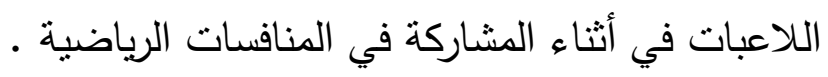

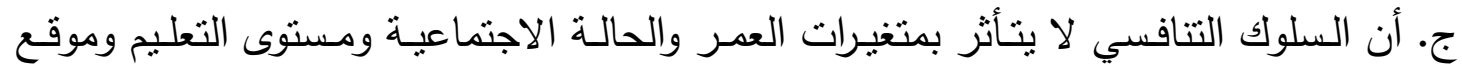
السكن ونوع الرياضة ودافع ممارسة الرياضة .

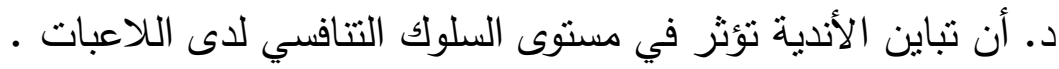

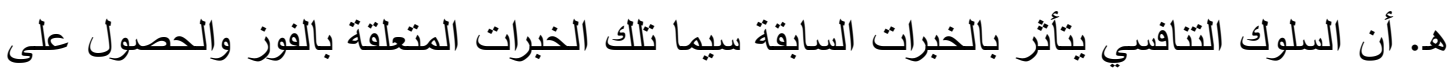

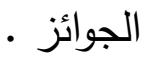

$$
\text { : }
$$

وفي ضوء النتائج التي أسفر عنها البحث يمكن تقديم التوصيات الآتية :

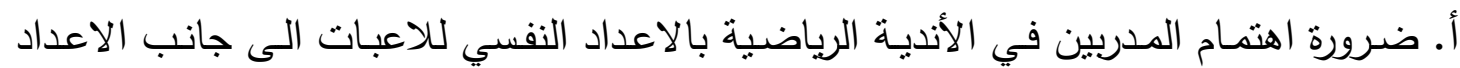

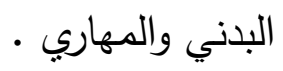

ب. العمل من أجل خلق حالة الاطمئنان النفسي لدى اللاعبات والحد من الخوف من الفنل

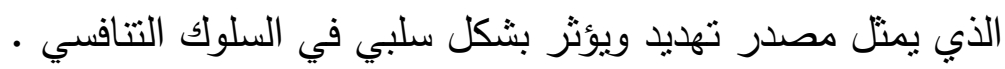

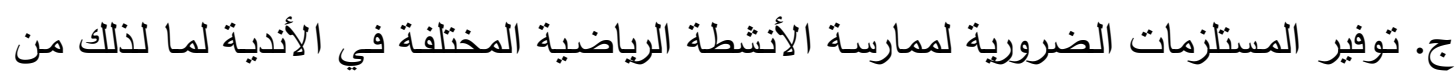
أثر ايجابي في سلوك المنافسة لدى اللاعبات .

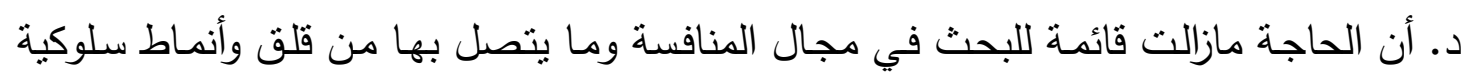

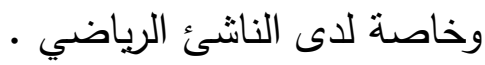

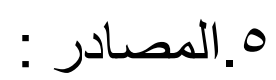

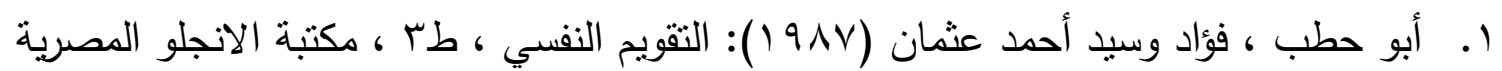


r. الأزيرجـاوي ، فاضل محسن (1991)): علم النفس التربوي ، دار الكتب لطباعـة ، جامعـة

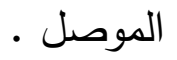

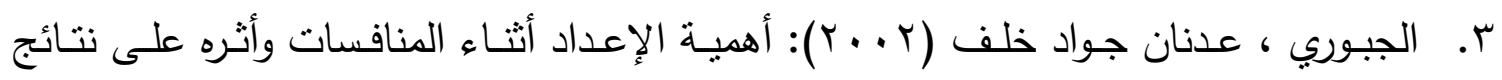

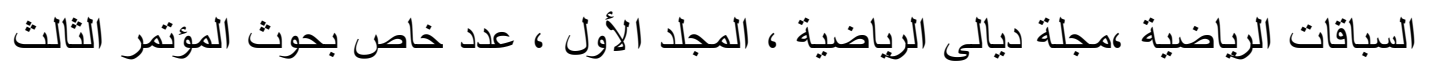

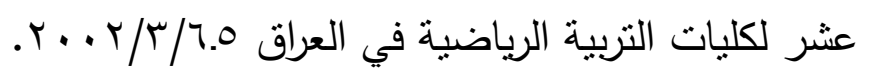

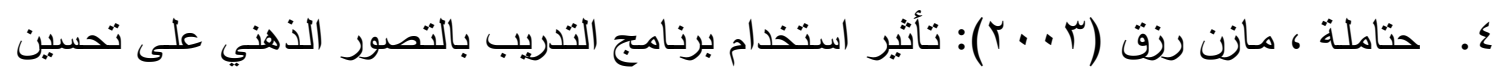

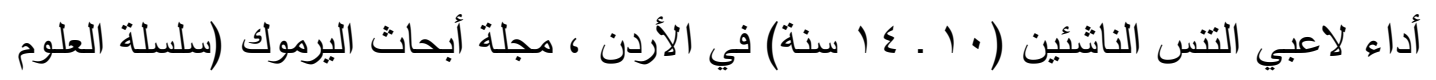

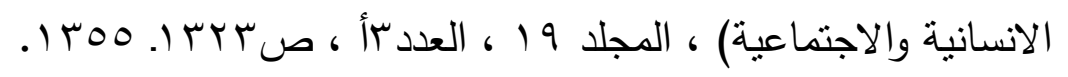

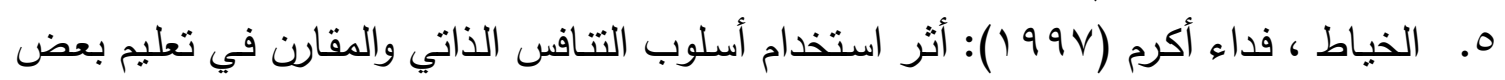

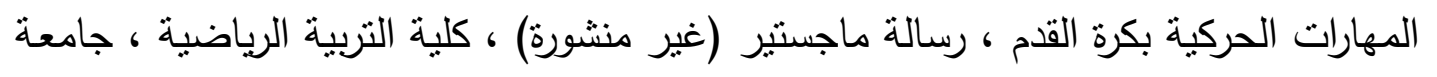

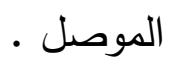

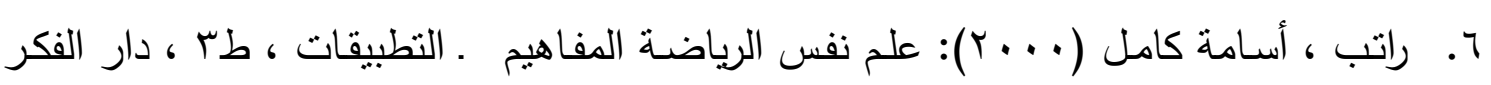

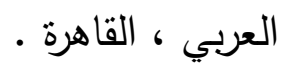
V. . الروسـان ، فــاروق (1999 (1): أسـاليب القيـاس والتشخيص فـي التربيـة ، طا ، دار الفكـر

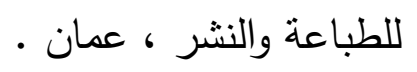

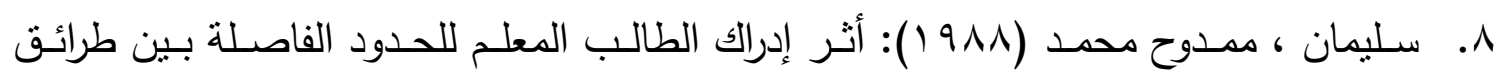

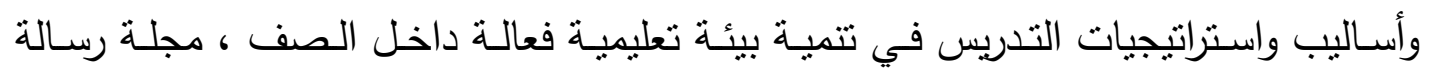

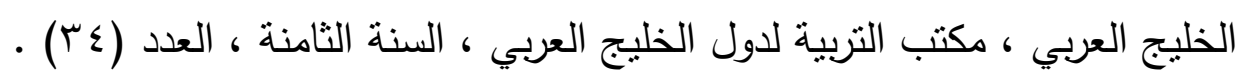

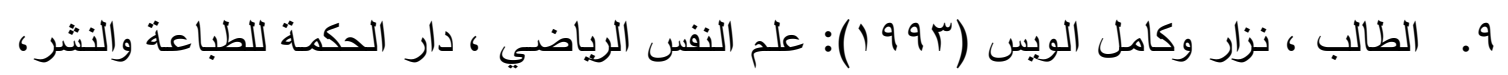

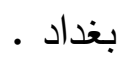

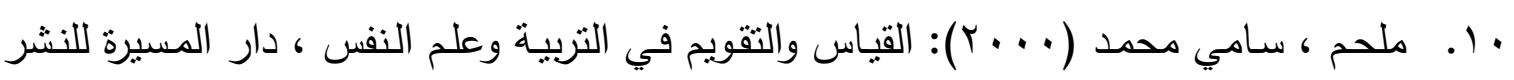

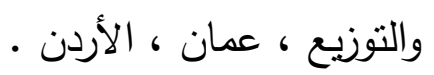

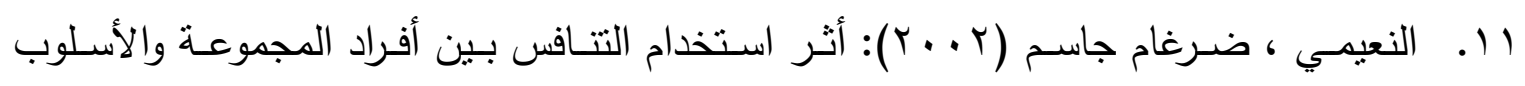

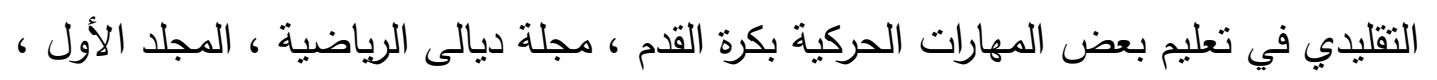

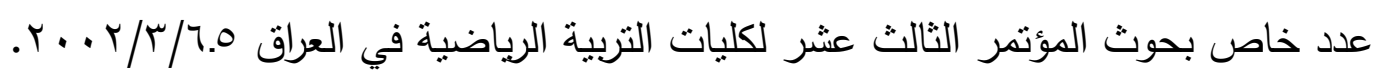
12. Wiliams, J.M.(1993): Applied Sport Psychology Personal Growth to Peak Performance, Mayfield Publishing Co., London. 

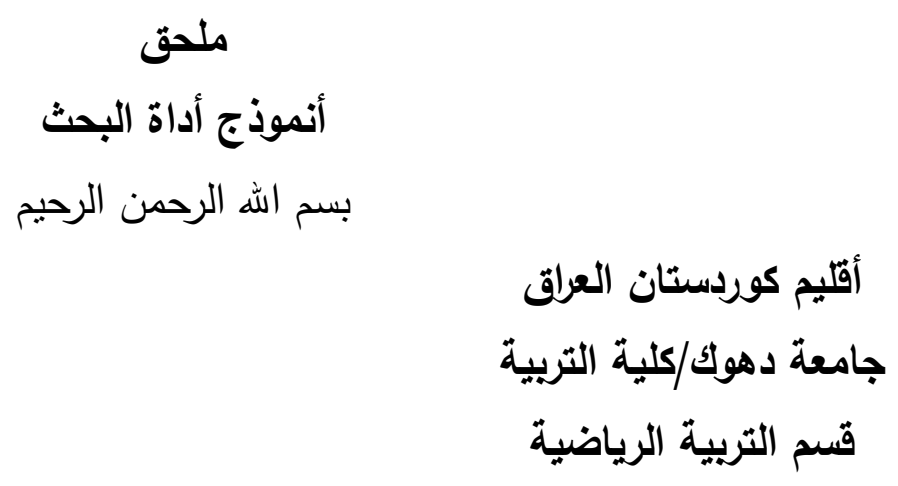

م/ استبيان

عزيزتي الرياضية ..

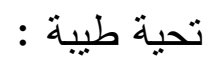

بهدف دراسة السلوك التتافسي لدى اللاعبات في الأندية الرياضية في محافظة دهوك

فقد تم إعداد هذا الاسنبيان ، لذا نرجوا قراءة كل فقرة من الفقرات ومن ثم الإجابة عنها باختيار

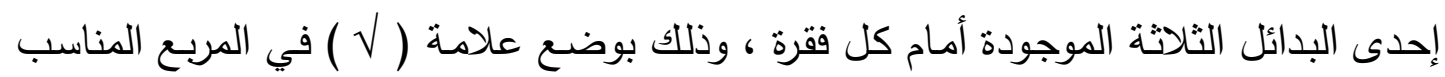

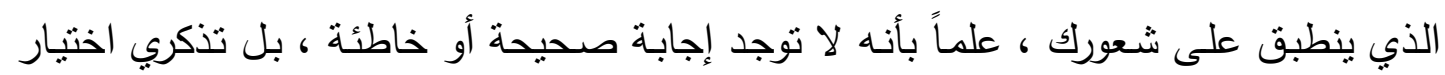

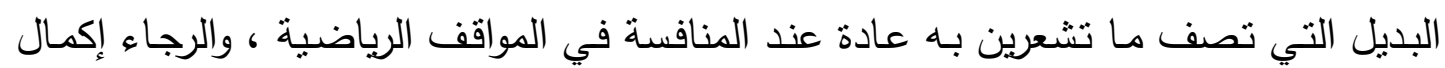

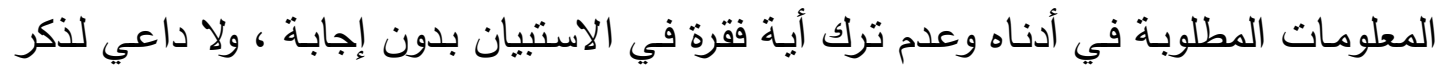

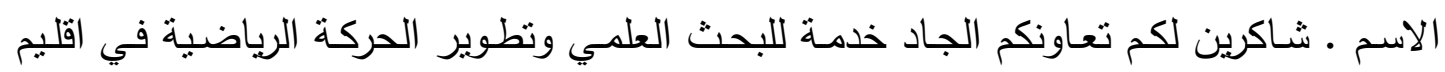

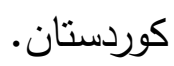

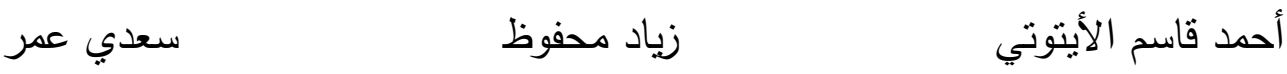

$$
\begin{aligned}
& \text { المعلومات : }
\end{aligned}
$$

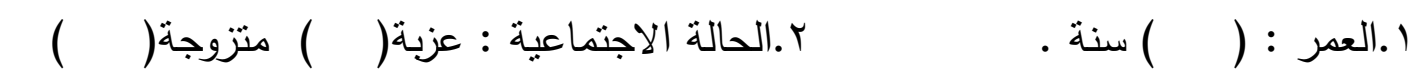

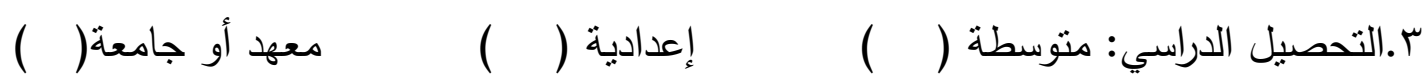

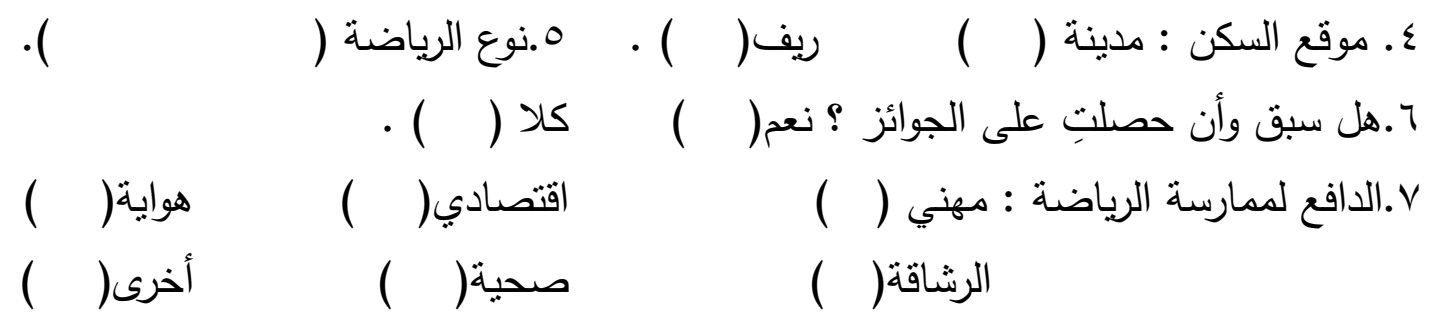

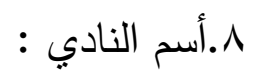




\begin{tabular}{|c|c|c|c|c|}
\hline أبداً & 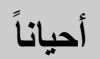 & دائماً & 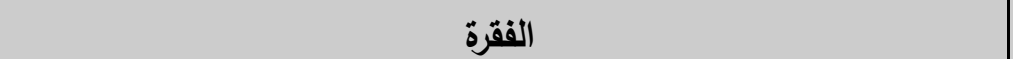 & $ت$ \\
\hline & & & ينخفض مستوى أدائي في المنافسة حينما يشاهدها بعض الأشخاص المهين & 1 \\
\hline & & & عندما أرتكب بعض الأخطـاء أثنـاء المنافسة فإنني لا أجد صـعوبة في & r \\
\hline & & & تزداد نقتي في نفسي كلما اقترب موعد المنافسة . & r \\
\hline & & & أعنف نفسي عندما أرتكب بعض الأخطاء أثثاء المنافسة . & $\varepsilon$ \\
\hline & & & 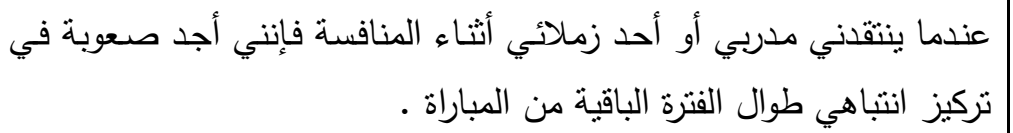 & 0 \\
\hline & & & تظهر قدراتي العالية بصورة واضحة أثناء المواقف الحساسة في المنافسة & 7 \\
\hline & & & أشعر بالقلق من عدم قدرتي على الأداء بصورة جيدة في المنافسة الهامة . & $\checkmark$ \\
\hline & & & قبل اشتراكي في المنافسة لا أحتاج للمزيد من الوقت لكي أستعد نفسياً وذهنياً & $\wedge$ \\
\hline & & & ينتابني القلق الثديد قبل اشتراكي في منافسة هامة . & 9 \\
\hline & & & عندما تسوء الأمور في المنافسة فإن ذلك لا يسبب لي الارتباك أو القلق . & 1. \\
\hline & & & أدائي في المنافسة أفضل من أدائي أثناء التدريب . & 11 \\
\hline & & & |لا في بعض قراراته . . أنثاء المنافسة عندما أعتقد أن الحكم قد أخطأ معي أو مع زملائي & it \\
\hline & & & بعد انتهاء المنافسة أستطيع أن أنذكر كل ما حدث في المنافسة . & ז \\
\hline & & & أخشى من احتمال اصابتي أثناء اشتراكي في المنافسة . & $1 \varepsilon$ \\
\hline & & & أضاول تجنب التفكير في المنافسة القادمـة لأن ذلك يسبب لي المزيد من & 10 \\
\hline & & & أشعر قبل اشتراكي في المنافسة مباشرة بأنني لا أستطيع تذكر أي شيء . & 17 \\
\hline & & & مستوى أدائي ثابت في المنافسة وفي أقصى حدود قدراتي • & iv \\
\hline & & & بعد انتهاء المنافسة أشعر بأنني كنت أستطيع الأداء بصورة أفضل . & 11 \\
\hline & & & أجد متعة في ممارسة الرياضة أثثاء المنافسة أكثر من التدريب. & 19 \\
\hline & & & أرتكب بعض الأخطاء في اللحظات الحساسة من المنافسة . & r. \\
\hline
\end{tabular}

